Atmos. Chem. Phys., 19, 11669-11685, 2019

https://doi.org/10.5194/acp-19-11669-2019

(C) Author(s) 2019. This work is distributed under

the Creative Commons Attribution 4.0 License.

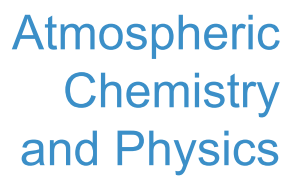

(c) (i)

\title{
Light absorption properties and potential sources of particulate brown carbon in the Pearl River Delta region of China
}

\author{
Zhujie Li ${ }^{1,2, a}$, Haobo Tan ${ }^{2,3}$, Jun Zheng ${ }^{1}$, Li Liu ${ }^{2,4}$, Yiming Qin ${ }^{5, b}$, Nan Wang ${ }^{2}$, Fei Li ${ }^{2}$, Yongjie $\mathbf{L i}^{6}$, Mingfu Cai ${ }^{4}$, \\ Yan $\mathrm{Ma}^{1}$, and Chak K. Chan ${ }^{5}$ \\ ${ }^{1}$ Collaborative Innovation Center of Atmospheric Environment and Equipment Technology, \\ Nanjing University of Information Science and Technology, Nanjing, China \\ ${ }^{2}$ Key Laboratory of Regional Numerical Weather Prediction, Institute of Tropical and Marine Meteorology, China \\ Meteorological Administration, Guangzhou, China \\ ${ }^{3}$ Foshan Meteorological Service of Guangdong, Foshan 528010, Guangdong, China \\ ${ }^{4}$ Department of Atmospheric Science, Sun yat-sen University, Guangzhou, China \\ ${ }^{5}$ School of Energy and Environment, City University of Hong Kong SAR, Hong Kong, China \\ ${ }^{6}$ Department of Civil and Environmental Engineering, Faculty of Science and Technology, University of Macau, \\ Macau SAR, China \\ ${ }^{a}$ Now at Emergency Early Warning Release and Weather Modification Center of Guangdong, Guangzhou 510080, China \\ ${ }^{\mathrm{b}}$ Now at School of Engineering and Applied Sciences, Harvard University, Cambridge, MA, USA
}

Correspondence: Haobo Tan (hbtan@gd121.cn) and Jun Zheng (zheng.jun@nuist.edu.cn)

Received: 21 December 2018 - Discussion started: 4 January 2019

Revised: 15 August 2019 - Accepted: 18 August 2019 - Published: 19 September 2019

\begin{abstract}
Brown carbon (BrC) is a special type of organic aerosol (OA), capable of absorbing solar radiation from nearultraviolet (UV) to visible wavelengths, which may lead to an increased aerosol radiative effect in the atmosphere. While high concentrations of OAs have been observed in the Pearl River Delta (PRD) region of China, the optical properties and corresponding radiative forcing of $\mathrm{BrC}$ in the PRD are still not well understood. In this work, we conducted a set of comprehensive measurements of atmospheric particulate matter from 29 November 2014 to 2 January 2015 to investigate aerosol compositions, optical properties, source origins, and radiative forcing effects at a suburban station in Guangzhou. The particle absorption Ångström exponent (AAE) was deduced and utilized to distinguish light absorption by $\mathrm{BrC}$ from that by black carbon (BC). The results showed that the average absorption contributions of $\mathrm{BrC}$ were $34.1 \pm 8.0 \%$ at $370 \mathrm{~nm}, 23.7 \pm 7.3 \%$ at $470 \mathrm{~nm}, 16.0 \pm 6.7 \%$ at $520 \mathrm{~nm}$, $13.0 \pm 5.4 \%$ at $590 \mathrm{~nm}$, and $8.7 \pm 4.3 \%$ at $660 \mathrm{~nm}$. A sensitivity analysis of the evaluation of the absorption Angström exponent of $\mathrm{BC}\left(\mathrm{AAE}_{\mathrm{BC}}\right)$ was conducted based on the Mie theory calculation assuming that the $\mathrm{BC}$-containing aerosol was mixed with the core-shell and external configurations.
\end{abstract}

The corresponding uncertainty in $\mathrm{AAE}_{\mathrm{BC}}$ was acquired. We found that variations in the imaginary refractive index (RI) of the $\mathrm{BC}$ core can significantly affect the estimation of $\mathrm{AAE} \mathrm{BC}_{\mathrm{BC}}$. However, $\mathrm{AAE}_{\mathrm{BC}}$ was relatively less sensitive to the real part of the RI of the BC core and was least sensitive to the real part of the RI of the non-light-absorbing shell. BrC absorption was closely related to aerosol potassium cation content $\left(\mathrm{K}^{+}\right)$, a common tracer of biomass burning emissions, which was most likely associated with straw burning in the rural area of the western PRD. Diurnal variation in BrC absorption revealed that primary organic aerosols had a larger $\mathrm{BrC}$ absorption capacity than secondary organic aerosols (SOAs). Radiative transfer simulations showed that $\mathrm{BrC}$ absorption may cause $2.3 \pm 1.8 \mathrm{~W} \mathrm{~m}^{-2}$ radiative forcing at the top of the atmosphere (TOA) and contribute to $15.8 \pm 4.4 \%$ of the aerosol warming effect. A chart was constructed to conveniently assess the $\mathrm{BrC}$ radiative forcing efficiency in the studied area with reference to certain aerosol single-scattering albedo (SSA) and $\mathrm{BrC}$ absorption contributions at various wavelengths. Evidently, the BrC radiative forcing efficiency was higher at shorter wavelengths. 


\section{Introduction}

Black carbon (BC) and organic carbon (OC) are dominant carbonaceous aerosol components that mainly originate from biomass burning on a global scale (Bond et al., 2004) and have caused great environmental concern in rapidly developing regions. Carbonaceous aerosols can not only exert adverse impacts on public health, similar to other particulate matters, but also significantly affect the terrestrial radiation balance with enormous uncertainties. In previous studies, BC was often considered to be the only light-absorbing species (Andreae and Gelencser, 2006), and OC was believed to only be able to scatter light, i.e., causing a cooling effect (Bond et al., 2011). Nevertheless, it has been reported that a fraction of organic aerosols (OAs) may also specifically contribute to light absorption from the near-ultraviolet (UV) to visible wavelength range, which is referred to as brown carbon (BrC) (Kirchstetter et al., 2004). BrC optical properties are strongly affected by its chemical composition and physical structure, which are related to different $\mathrm{BrC}$ sources. $\mathrm{BrC}$ can originate not only from direct emissions, including smoldering, biomass burning, or any type of incomplete fuel combustion process (Cheng et al., 2011; T. C. Bond et al., 1999), but also from secondary organic aerosol formation processes, such as aqueous phase reactions in acidic solutions (Desyaterik et al., 2013) or volatile organic compound (VOC) oxidation (Laskin et al., 2015; Sareen et al., 2010). In addition, $\mathrm{BrC}$ could have a complicated molecular composition and intermix with other substances, such as BC, non-absorbing OAs, and other inorganic materials, making it complicated to investigate $\mathrm{BrC}$ optical properties.

$\mathrm{BC}$ absorption is commonly assumed to cover the full wavelength range. However, the light absorption property of $\mathrm{BrC}$ is believed to be more wavelength-dependent, which can be represented by distinct absorption Ångström exponent (AAE) values, i.e., the power exponent of the light absorption coefficient. A typical threshold for the AAE of $\mathrm{BC}\left(\mathrm{AAE}_{\mathrm{BC}}\right)$ of 1.6 has been recommended to distinguish $\mathrm{BrC}$ from $\mathrm{BC}$ (Lack and Cappa, 2010), and the AAE of BrC has been reported as having a wider range (2 to 7) (Hoffer et al., 2006). Based on the difference in the wavelength dependence of light absorption between $\mathrm{BC}$ and $\mathrm{BrC}$, previous studies have applied the AAE method to differentiate light absorption by $\mathrm{BrC}$ through multiwavelength optical measuring apparatus, such as a three-wavelength photoacoustic soot spectrometer (PASS-3) (Lack and Langridge, 2013) and a multiwavelength Aethalometer (Olson et al., 2015). Based on the AAE method, the $\mathrm{BrC}$ absorption contribution has been estimated to be approximately $6 \%$ to $41 \%$ of total aerosol light absorption at short wavelengths, e.g., at 370 and $405 \mathrm{~nm}$ (Washenfelder et al., 2015). A uniform $\mathrm{AAE}_{\mathrm{BC}}$ from $\sim 300 \mathrm{~nm}$ up to $\sim 700 \mathrm{~nm}$ (Moosmüller et al., 2011) is commonly used when evaluating the $\mathrm{BrC}$ absorption contribution using the $\mathrm{AAE}$ method. However, it has been reported that the $\mathrm{AAE}_{\mathrm{BC}}$ can be influenced by the mixing state, $\mathrm{BC}$ core size, and mor- phology (Lack and Cappa, 2010). The lensing effect of the coating shell may enhance BC light absorption, the magnitude of which may also depend on wavelength and can alter the value of $\mathrm{AAE}_{\mathrm{BC}}$ (Liu et al., 2018). Moreover, different values of $\mathrm{AAE}_{\mathrm{BC}}$ have been found in the near-infrared and UV ranges (Wang et al., 2018). Therefore, using the default value of $\mathrm{AAE}_{\mathrm{BC}}=1$ may lead to uncertainty in $\mathrm{BrC}$ absorption coefficient estimation.

Quantifying BrC optical absorption accurately is essential to interpret aerosol optical depth (AOD), and the corresponding aerosol direct radiative forcing (DRF) on the atmosphere can also be evaluated if the single-scattering albedo (SSA) and extinction coefficient of aerosols are known. The estimation of the DRF of $\mathrm{BrC}$ has shown a distinct seasonal variation, indicating the influence of different absorption properties of BrC (Arola et al., 2015). A global simulation study indicated that the average warming effect at the top of the atmosphere (TOA) caused by $\mathrm{BrC}$ absorption can be up to $0.11 \mathrm{~W} \mathrm{~m}^{-2}$, corresponding to $\sim 25 \%$ of that predicted from BC absorption only (Feng et al., 2013).

During the last 3 decades, rapid economic development has led to severe air pollution problems in the Pearl River Delta (PRD) region (Chan and Yao, 2008). With rapid increases in the automobile population and factories, high loadings of secondary organic aerosols (SOAs) have often been observed (Tan et al., 2016b). Biofuel usage may also play a significant role during wintertime air pollution events in the $\mathrm{PRD}$, indicating that the contribution from $\mathrm{BrC}$ light absorption cannot be ignored (Wu et al., 2018). Recently, BrC light absorption has been quantified by Qin et al. (2018) using the AAE method in the PRD region. OA chemical composition was simultaneously measured by a high-resolution time-offlight aerosol mass spectrometer, and it was found that organic aerosols originating from biomass burning possessed the most intense absorption capability and were largely responsible for $\mathrm{BrC}$ absorption. Qin et al. (2018) also suggested that correlations between OA chemical compositions and $\mathrm{BrC}$ absorption were wavelength-dependent.

In this paper, we applied the homologous AAE differentiation method to quantify the fraction of aerosol light absorption by $\mathrm{BrC}$ using the measurements from a sevenwavelength Aethalometer. The potential error incurred with this methodology was determined using Mie theory simulations, especially for various complex refractive indexes of the $\mathrm{BC}$ core and the coating material. The correlation between $\mathrm{BrC}$ light absorption and water-soluble ions, which is used as the source tracer, was employed to identify potential $\mathrm{BrC}$ sources. An atmospheric radiative transfer model has also been applied to evaluate the impact of $\mathrm{BrC}$ on direct radiative forcing using surface-based aerosol optical properties and satellite-based surface-albedo data. The magnitudes of aerosol radiative forcing at the top of the atmosphere due to $\mathrm{BC}$ and $\mathrm{BrC}$ were also individually quantified. 


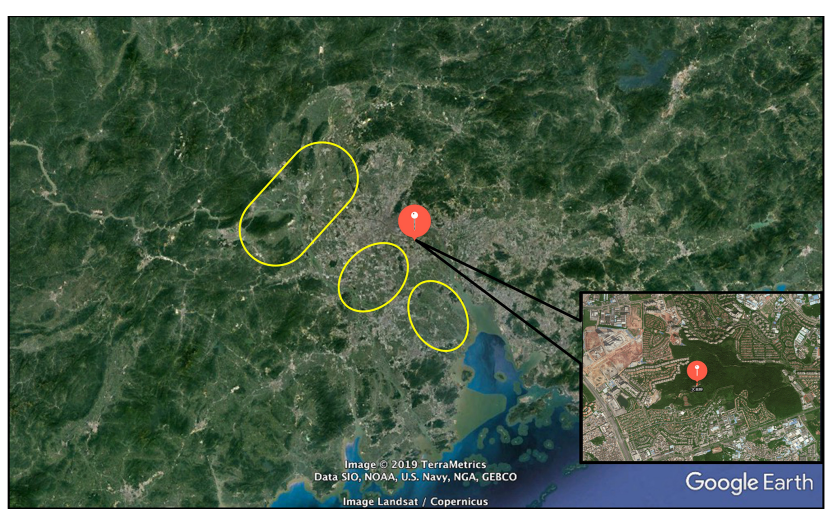

Figure 1. The location of Panyu station (CAWNET) in the PRD region (indicated by the red dot). The plain areas within the yellow circles are the main rural areas of the western PRD. () Google Earth.

\section{Methodology}

\subsection{Sampling site}

Field observations were conducted at the Panyu station $\left(23^{\circ} 00^{\prime} \mathrm{N}, 113^{\circ} 21^{\prime} \mathrm{E}\right)$, which is a monitoring site of the Chinese Meteorological Administration (CMA) Atmospheric Watch Network (CAWNET) that is located on the summit of Dazhengang Mountain (approximately $150 \mathrm{~m}$ above sea level) in Guangzhou, China. Figure 1 shows the location of the Panyu site, which is situated at the center of the PRD and is separated from residential areas by at least $500 \mathrm{~m}$. Some agricultural fields can be found to the west of the site. Although there were no significant pollution sources nearby, this suburban site was strongly affected by pollutants transported from the urban area of Guangzhou and crop residual fires transported from the rural area of the PRD. The field campaign was conducted from 29 November 2014 to 2 January 2015. During the measurement period, aerosol light scattering and extinction, $\mathrm{BC}$ concentration, particle number size distribution (PNSD), OC concentration, and the watersoluble ion concentrations of $\mathrm{PM}_{2.5}$ were continuously monitored.

\subsection{Measurements and data analysis}

All instruments were housed inside the second-floor measurement room of a $\sim 5 \mathrm{~m}$ tall, two-story building. The ambient sample was taken on the roof by a $2 \mathrm{~m}$ long, $12.7 \mathrm{~mm}$ OD stainless steel inlet, and a $\mathrm{PM}_{2.5}$ cyclone sampler was also used. The metal tubing was thermally insulated and maintained at a constant temperature of $\sim 25^{\circ} \mathrm{C}$. A diffusion drier was also used in-line to dry the relative humidity (RH) of the air sample to below $30 \%$ before further analysis.

\subsubsection{Measurements of relevant species}

A TSI-3936 scanning mobility particle sizer (SMPS) and a TSI-3321 aerodynamic particle sizer (APS) were utilized to measure the 10 to $500 \mathrm{~nm}$ mobility diameter and 0.5 to $2.5 \mu \mathrm{m}$ aerodynamic diameter of the PNSD, respectively. The aerodynamic diameters of the APS data were converted into mobility diameters using a material density of $1.7 \mathrm{~g} \mathrm{~cm}^{-3}$. A detailed data merging method has been described by Cheng et al. (2006). Furthermore, the pipe diffusion loss of SMPS has been corrected using the empirical formula proposed by Kulkarni et al. (1996).

An AE-33 Aethalometer (Magee Scientific Inc.) was utilized for BC mass concentration measurement, which was derived from optical attenuation using a mass absorption cross section (MAC) of $7.77 \mathrm{~m}^{2} \mathrm{~g}^{-1}$ at $880 \mathrm{~nm}$. The sensitivity of AE-33 was approximately $0.03 \mu \mathrm{g} \mathrm{m}^{-3}$ for a $1 \mathrm{~min}$ time resolution and a 5.0 liter per minute $\left(\mathrm{L} \mathrm{min}^{-1}\right)$ sample flow rate.

The $\mathrm{PM}_{2.5}$ mass concentration was measured by an environmental dust monitor (model EDM180, GRIMM Inc.), which monitored the mass concentration of $\mathrm{PM}_{2.5}$ and $\mathrm{PM}_{10}$ simultaneously.

Water-soluble ions (potassium $\left(\mathrm{K}^{+}\right)$, calcium $\left(\mathrm{Ca}^{2+}\right)$, magnesium $\left(\mathrm{Mg}^{2+}\right)$, chloride $\left(\mathrm{Cl}^{-}\right)$, sulfate $\left(\mathrm{SO}_{4}^{2-}\right)$, nitrate $\left(\mathrm{NO}_{3}^{-}\right)$, and ammonium $\left(\mathrm{NH}_{4}^{+}\right)$were measured with the Monitor for AeRosols and Gases in Air (MARGA) (Model ADI2080, Metrohm Inc.), which is an online analyzer for semicontinuous measurements of gases and water-soluble ions in aerosols ( $\mathrm{Li}$ et al., 2010). The MARGA was automatically calibrated with standard internal solutions during field measurement. The MARGA utilized its own $\mathrm{PM}_{2.5}$ sampling system provided by the manufacturer.

The OC and elemental carbon (EC) were measured by a Sunset online OC/EC analyzer (Model RT-4) with a laser transmittance-based charring correction (Wu et al., 2018, 2019). The sample flow rate of the OC/EC analyzer was maintained at $8 \mathrm{~L} \mathrm{~min}^{-1}$. For each measurement cycle $(1 \mathrm{~h})$, samples were collected onto a quartz filter within the first $45 \mathrm{~min}$ and then thermal-optically analyzed during the remaining $15 \mathrm{~min}$. First, OC was completely volatized in oxygen-free helium with a temperature ramped stepwise $\left(600\right.$ and $\left.840^{\circ} \mathrm{C}\right)$. In the second stage, the temperature was reduced to $550{ }^{\circ} \mathrm{C}$, and then $\mathrm{EC}$ and pyrolyzed carbon (PC) were combusted in an oxidizing atmosphere $(10 \%$ oxygen in helium), while the temperature was increased up to $870^{\circ} \mathrm{C}$ step by step. The $\mathrm{CO}_{2}$ converted from all of the carbon components was then quantified by a nondispersive infrared absorption $\mathrm{CO}_{2}$ sensor (Lin et al., 2009). An internal calibration peak made by $5 \%$ methane in helium was applied to quantify OC and EC. To correct the PC converted from OC to EC, a tunable pulsed diode laser beam was used to monitor the laser transmittance through the quartz filter throughout the thermal-optical analysis (Bauer et al., 2012). 


\subsubsection{Measurements of optical properties}

Light extinction by aerosols at $532 \mathrm{~nm}$ was detected using a cavity ring-down aerosol extinction spectrometer (CRDS) (Model XG-1000, Hexin Inc.) by measuring the decay times of laser intensity through the aerosol-containing sample and the filtered background air sample under the same conditions. The extinction coefficient $\left(\sigma_{\text {ext }}\right)$ was calculated using the procedure described by Khalizov et al. (2009).

Aerosol total scattering $\left(\sigma_{\mathrm{sp}}\right)$ was measured by a TSI-3563 integrated nephelometer at three wavelengths (i.e., 450, 550, and $700 \mathrm{~nm}$ ) and was calibrated with $\mathrm{CO}_{2}$ following the manual instructions. Particle-free air was used to check the nephelometer background signal once every $2 \mathrm{~h}$. The scattering coefficients at other wavelengths were extrapolated using the following equations:

$\mathrm{SAE}=-\frac{\ln \left(\sigma_{\mathrm{scat}, \lambda_{0}}\right)-\ln \left(\sigma_{\mathrm{scat}, 550 \mathrm{~nm}}\right)}{\ln \left(\lambda_{0}\right)-\ln (550)}$,

$\sigma_{\text {scat }}(\lambda)=\sigma_{\text {scat }}(550) \cdot\left(\frac{\lambda}{550}\right)^{-\mathrm{SAE}}$,

where $\lambda_{0}=450 \mathrm{~nm}$ is for wavelengths less than $550 \mathrm{~nm}$ and $\lambda_{0}=700 \mathrm{~nm}$ is for wavelengths greater than $550 \mathrm{~nm}$. The corresponding time series of extinction coefficients, scattering coefficients, and SSA at $532 \mathrm{~nm}$ are displayed in Fig. S1 in the Supplement.

The Aethalometer was also used for multi-wavelength light absorption measurements in this study. The sevenwavelength aerosol light attenuation coefficients $\left(\sigma_{\text {ATN }}\right)$ were converted into aerosol light absorption coefficients $\left(\sigma_{\text {abs }}\right)$ using Eq. (3) (Coen et al., 2010), where $k$ is the parameter that accounts for the loading effect, ATN is the light attenuation through the filter with sample loading, and $C_{\text {ref }}$ is a fixed multiple scattering parameter.

$\sigma_{\mathrm{abs}}=\frac{\sigma_{\mathrm{ATN}}}{(1-k \cdot \mathrm{ATN}) \cdot C_{\mathrm{ref}}}$

The real-time $k$ value was retrieved using the dual-spot loading correction algorithm developed by Drinovec et al. (2015). The detailed formula of ATN can also be found in Drinovec et al. (2015). $C_{\text {ref }}$ is considered a constant that strongly depends on the filter matrix effect. However, some studies have suggested that $C_{\text {ref }}$ may vary with wavelength (Arnott et al., 2005; Segura et al., 2014). For internal combustion engines and biomass burning, $C_{\text {ref }}$ at $370 \mathrm{~nm}$ was expected to be approximately $12 \%$ and $18 \%$ less than $C_{\text {ref }}$ at $532 \mathrm{~nm}$ for the aerosol component, respectively (Schmid et al., 2006). Different ambient observations also showed that $C_{\text {ref }}$ may have regional specificity, even though it was retrieved by the same methodology (Coen et al., 2010). In this study, $C_{\text {ref }}=3.29$ was used in Eq. (3) at each wavelength, and this value was derived from the slope of $\sigma_{\mathrm{ATN}}$ measured by the Aethalometer vs. $\sigma_{\mathrm{abs}}$, which was deduced from the CRDS and nephelometer measurements. This $C_{\text {ref }}$ was also very similar to the $C_{\text {ref }}$ of 3.48 determined from an intercomparison study between an Aethalometer and a photoacoustic soot spectrometer during a field campaign conducted in the PRD region in 2004 (Wu et al., 2009).

The BC light absorption at certain wavelengths was derived from the absorption coefficient $\sigma_{\mathrm{abs}}$ according to BeerLambert's law, and its variation between different pairs of wavelengths (i.e., $\sigma_{\mathrm{abs}, \mathrm{BC}, \lambda}$ ) is denoted by the absorption AAE equation developed by Ångström (1929):

$\sigma_{\mathrm{abs}, \mathrm{BC}, \lambda}=\sigma_{\mathrm{abs}, \mathrm{BC}, \lambda_{0}} \times\left(\lambda_{0} / \lambda\right)^{\mathrm{AAE}_{\mathrm{BC}}}$.

It has been suggested that the AAE of BC may vary between short and long wavelength ranges (Lack and Cappa, 2010); hence, applying a wavelength-independent $\mathrm{AAE}_{\mathrm{BC}}$ may lead to uncertainties in the $\mathrm{BC}$ absorption calculation from one wavelength to another. In this work, the light absorptions of $\mathrm{BC}$ at various wavelengths were retrieved by a modified wavelength-dependent AAE differentiation method conducted by Wang et al. (2018):

$\sigma_{\mathrm{abs}, \mathrm{BC}, \lambda_{1}}=\sigma_{\mathrm{abs}, \mathrm{BC}, 880 \mathrm{~nm}} \times\left(\frac{880}{\lambda_{1}}\right)^{\mathrm{AAE}_{\mathrm{BC}, 520-880 \mathrm{~nm}},}$

$$
\begin{aligned}
\sigma_{\mathrm{abs}, \mathrm{BC}, \lambda_{2}} & =\sigma_{\mathrm{abs}, \mathrm{BC}, 880 \mathrm{~nm}} \times\left(\frac{880}{520}\right)^{\mathrm{AAE}_{\mathrm{BC}, 520-880 \mathrm{~nm}}} \\
& \times\left(\frac{520}{\lambda_{2}}\right)^{\mathrm{AAE} \mathrm{BC}_{3}, 370-520 \mathrm{~nm}}
\end{aligned}
$$

Here, $\sigma_{\mathrm{abs}, \mathrm{BC}, \lambda_{1}}$ represents the absorption coefficient due to only $\mathrm{BC}$ greater than $520 \mathrm{~nm}$, and $\sigma_{\mathrm{abs}, \mathrm{BC}, \lambda_{2}}$ represents the absorption coefficient of BC less than $520 \mathrm{~nm}$. $\mathrm{AAE} \mathrm{BC}_{\lambda_{i}-\lambda_{i+1}}(i=1,2$, and 3$)$ represents the AAE of BC between a longer and shorter wavelength at $\lambda_{i}=880,520$, and $370 \mathrm{~nm}$ and was calculated as

$\mathrm{AAE}_{\mathrm{BC}, \lambda_{i}-\lambda_{i+1}}=-\frac{\ln \left(\sigma_{\mathrm{abs}, \mathrm{BC}, \lambda_{i}}\right)-\ln \left(\sigma_{\mathrm{abs}, \mathrm{BC}, \lambda_{i+1}}\right)}{\ln \left(\lambda_{i}\right)-\ln \left(\lambda_{i+1}\right)}$.

Accordingly, $\mathrm{BrC}$ absorption at a certain wavelength $\lambda$ $\left(\sigma_{\mathrm{abs}, \mathrm{BrC}, \lambda}\right)$ was equal to the value of total aerosol absorption $\left(\sigma_{\mathrm{abs}, \lambda}\right)$ minus BC absorption $\left(\sigma_{\mathrm{abs}, \mathrm{BC}, \lambda}\right)$ :

$\sigma_{\mathrm{abs}, \mathrm{BrC}, \lambda}=\sigma_{\mathrm{abs}, \lambda}-\sigma_{\mathrm{abs}, \mathrm{BC}, \lambda}$

The light absorption data at $880 \mathrm{~nm}\left(\sigma_{\mathrm{abs}, 880 \mathrm{~nm}}\right)$ were selected to represent $\mathrm{BC}$ absorption $\left(\sigma_{\mathrm{abs}, \mathrm{BC}, 880 \mathrm{~nm}}\right)$, which should not be affected by $\mathrm{BrC}$ (Drinovec et al., 2015). It has been reported that the dust-related contributions of $\mathrm{PM}_{2.5}$ were normally less than $5 \%$ in wintertime in Guangzhou; therefore, the influence from dust could be negligible in this study (Huang et al., 2014). 


\subsubsection{Estimation of $\mathrm{AAE}_{\mathrm{BC}}$}

Traditionally, $\mathrm{AAE}_{\mathrm{BC}}$ was believed to be close to 1.0 (Bodhaine, 1995), which has been commonly used for BC measurements (Olson et al., 2015). However, studies have demonstrated that $\mathrm{AAE}_{\mathrm{BC}}$ can be affected by the refractive index of coating materials, mixing state, morphology, and $\mathrm{BC}$ core size (Liu et al., 2015). Therefore, using the default $\mathrm{AAE}_{\mathrm{BC}}=1$ may lead to uncertainty in $\mathrm{BrC}$ absorption estimation. To obtain the correct $\mathrm{AAE}_{\mathrm{BC}}$, a series of Mie theory calculations were conducted using a simplified core-shell model (Bohren and Huffman, 1983; Wang et al., 2018). We used a modified BHCOAT code and BHMIE code to calculate the aerosol optical properties of the core-shell and external mixture at different wavelengths (Cheng et al., 2006). In the Mie theory, a particle is taken as a perfect homogeneous sphere, and its extinction and scattering efficiencies, $Q_{\text {ext,Mie, } \lambda}$ and $Q_{\text {scat,Mie, } \lambda}$, respectively, are expressed as (Mie, 1908; Seinfeld and Pandis, 1998)

$\alpha Q_{\text {ext,Mie }, \lambda}=\frac{2}{\lambda^{2}} \sum_{n=1}^{\infty}\left[(2 n+1) \operatorname{Re}\left(a_{n}+b_{n}\right)\right]$,

$\alpha Q_{\text {scat }, \text { Mie }, \lambda}=\frac{2}{\lambda^{2}} \sum_{n=1}^{\infty}\left[(2 n+1)\left(\left|a_{n}\right|^{2}+\left|b_{n}\right|^{2}\right)\right]$,

where $\alpha=\pi D_{\mathrm{p}} / \lambda$ is the size parameter; $a_{n}$ and $b_{n}$ are functions of the complex refractive index (RI) and $\alpha$ in the Riccati-Bessel form, respectively. Re in Eq. (8) denotes that only the real part of RI is taken. The absorption efficiency $\left(Q_{\mathrm{abs}, \mathrm{Mie}, \lambda}\right)$ is thus the difference between the extinction and scattering efficiencies:

$Q_{\mathrm{abs}, \mathrm{Mie}, \lambda}=Q_{\mathrm{ext}, \mathrm{Mie}, \lambda}-Q_{\mathrm{scat}, \mathrm{Mie}, \lambda}$.

Then, the absorption coefficient $\sigma_{\mathrm{abs}, \mathrm{Mie}, \lambda}$ was obtained by the following (Bricaud and Morel, 1986):

$\sigma_{\mathrm{abs}, \mathrm{Mie}, \lambda}=\int Q_{\mathrm{abs}, \mathrm{Mie}, \lambda} \cdot\left(\frac{\pi}{4} D_{\mathrm{p}}^{2}\right) \cdot N\left(\log D_{\mathrm{p}}\right) \cdot d \log D_{\mathrm{p}}$,

where $N\left(\log D_{\mathrm{p}}\right)$ is the PNSD function. A two-component parameterization of dry particles, i.e., the $\mathrm{BC}$ core and the non-light-absorbing species, was applied to calculate aerosol optical properties here (Wex et al., 2002). $\widetilde{m}_{\text {core }}$ represents the RI of the BC core, and $\widetilde{m}_{\text {non }}$ represents the RI of nonlight-absorbing particles.

In a realistic atmosphere, some non-light-absorbing particles may exist independently without BC (Liu et al., 2013; Cheung et al., 2016). In this work, the portion of non-lightabsorbing particles at a certain size $\left(D_{\mathrm{p}}\right)$ was determined by our previous measurements at the same site using a volatility tandem differential mobility analyzer (V-TDMA), during which completely vaporized (CV) particles at $300^{\circ} \mathrm{C}$ were referred to as non-light-absorbing particles that externally mixed with other BC-containing particles. Thus, the PNSD of $\mathrm{CV}$ particles $\left(N\left(\log D_{\mathrm{p}}\right)_{\mathrm{CV}}\right)$ and $\mathrm{BC}$-containing particles $\left(N\left(\log D_{\mathrm{p}}\right)_{\mathrm{BC}}\right)$ can be given by the following equations:

$$
\begin{aligned}
& N\left(\log D_{\mathrm{p}}\right)_{\mathrm{CV}}=N\left(\log D_{\mathrm{p}}\right)_{\text {measure }} \cdot \Phi\left(D_{\mathrm{p}}\right)_{N, \mathrm{CV}}, \\
& N\left(\log D_{\mathrm{p}}\right)_{\mathrm{BC}}=N\left(\log D_{\mathrm{p}}\right)_{\text {measure }} \cdot\left(1-\Phi\left(D_{\mathrm{p}}\right)_{N, \mathrm{CV}}\right),
\end{aligned}
$$

where $N\left(\log D_{\mathrm{p}}\right)_{\text {measure }}$ is the PNSD of the measured particles from SMPS and APS. $\Phi\left(D_{\mathrm{p}}\right)_{N, \mathrm{CV}}$ was the number fraction of $\mathrm{CV}$ particles in different size bins.

A previous study applied three kinds of $\mathrm{BC}$ mixture models to calculate the aerosol optical properties, including external, homogeneously internal, and core-shell mixtures (Bohren and Huffman, 2007; Seinfeld and Pandis, 1998). To quantify the mixing state of $\mathrm{BC}, r_{\mathrm{ext}}$ was defined as the mass fraction of externally mixed $\mathrm{BC}\left(M_{\mathrm{ext}}\right)$ in total $\mathrm{BC}\left(M_{\mathrm{BC}}\right)$ :

$r_{\mathrm{ext}}=\frac{M_{\mathrm{ext}}}{M_{\mathrm{BC}}}$.

Tan et al. (2016a) suggested that two extreme conditions of external and core-shell mixtures comprised the actual mixing state of $\mathrm{BC}$ in the PRD. Hence, we simply divided the PNSD of BC into the PNSD from an external mixture of BC and a core-shell mixture of BC. The PNSDs of externally mixed $\mathrm{BC}$ particles and core-shell mixed $\mathrm{BC}$ particles were referred to by the following equations with a given $r_{\mathrm{ext}}$.

$N\left(\log D_{\mathrm{p}}\right)_{\text {ext }}=N\left(\log D_{\mathrm{p}}\right)_{\mathrm{BC}} \cdot f_{\mathrm{BC}} \cdot r_{\mathrm{ext}}$
$N\left(\log D_{\mathrm{p}}\right)_{\text {core-shell }}=N\left(\log D_{\mathrm{p}}\right)_{\mathrm{BC}} \cdot\left(1-f_{\mathrm{BC}} \cdot r_{\mathrm{ext}}\right)$

$f_{\mathrm{BC}}$ was defined as the $\mathrm{BC}$ volume fraction in the $\mathrm{BC}$ containing particle volume, which can be converted from the $\mathrm{BC}$ mass concentration:

$f_{\mathrm{BC}}=\frac{M_{\mathrm{BC}}}{\rho_{\mathrm{BC}} \cdot \sum_{D_{\mathrm{P}}} N\left(\log D_{\mathrm{p}}\right)_{\mathrm{BC}} \cdot\left(\frac{\pi}{6} \cdot D_{\mathrm{p}}^{3}\right)}$,

where $\rho_{\mathrm{BC}}$ is the density of $\mathrm{BC}$ and is assumed to be $1.5 \mathrm{~g} \mathrm{~cm}^{-3}$ (Ma et al., 2012); $M_{\mathrm{BC}}$ is the BC mass concentration derived from the multi-angle absorption photometer (MAAP), which was obtained by an empirical formula from the Aethalometer that measured the BC concentration $\left(M_{\mathrm{BC}, \mathrm{AE}}\right)$, as proposed by $\mathrm{Wu}$ et al. (2009):

$M_{\mathrm{BC}}=0.897 \cdot M_{\mathrm{BC}, \mathrm{AE}}-0.062$.

The PNSDs of externally mixed non-light-absorbing particles and externally mixed $\mathrm{BC}$ particles were input into the BHMIE code, and the PNSD of the core-shell mixed particles was imported into the BHCOAT code. Another critical parameter for the core-shell model was the diameter of the BC core. For the simplified core-shell model we applied, the visualization was that a homogeneous $\mathrm{BC}$ core sphere was encapsulated in a shell of non-absorbing coating (Bohren and Huffman, 2007). Without size-resolved coating thickness measurements, core-shell mixed particles simply assumed 
that cores with the same diameter had the same coating thickness. Therefore, the diameter of the $\mathrm{BC}$ core was calculated as follows:

$D_{\text {core }}=D_{\mathrm{p}} \cdot\left(\frac{f_{\mathrm{BC}}-f_{\mathrm{BC}} \cdot r_{\mathrm{ext}}}{1-f_{\mathrm{BC}} \cdot r_{\mathrm{ext}}}\right)^{\frac{1}{3}}$.

$D_{\text {core }}$ and $D_{\mathrm{p}}$ are inputted as parameters into $a_{n}$ and $b_{n}$, respectively, which was described by Bohren and Huffman (2007). The corresponding time series of size distribution of the derived external $\mathrm{BC}$ and internal $\mathrm{BC}$ core are illustrated in Fig. S2. Thus, the $\sigma_{\mathrm{abs}, \mathrm{BC}, \mathrm{Mie}, \lambda_{i}}$ values of all six wavelengths were calculated through the Mie model, and then the $\mathrm{AAE}_{\mathrm{BC}}$ values of those five wavelengths were obtained using Eq. (6). The performance of this empirically determined calculation method has been compared with other possible $\mathrm{BC}$ mixing schemes in detail (see Table 1).

\subsubsection{Atmospheric radiative transfer model}

In this work, the Santa Barbara DISORT Atmospheric Radiative Transfer (SBDART) model was employed to estimate the DRF of BrC absorption, i.e., its effects on the downward and upward fluxes $\left(F\right.$ in $\left.\mathrm{W} \mathrm{m}^{-2}\right)$ of solar radiation at the TOA. SBDART is a software tool that can be used to compute plane-parallel radiative transfer under both clear and cloudy conditions within the atmosphere. More details about this model are found in Ricchiazzi et al. (1998). Both ground measurements and remote-sensing data were used in the simulation. The surface albedo was derived from a $500 \mathrm{~m}$ resolution Moderate Resolution Imaging Spectroradiometer (MODIS) Bidirectional Reflectance Distribution Function (BRDF) albedo model parameter product (MCD43A3, daily). The MCD43A3 products are the total shortwave broadband black-sky albedo $\left(\alpha_{\mathrm{BSA}}\right)$ and whitesky albedo $\left(\alpha_{\text {WSA }}\right)$, while the actual surface albedo $(\alpha)$ was computed from a linear combination of $\alpha_{\mathrm{WSA}}$ and $\alpha_{\mathrm{BSA}}$, which were weighted by the diffuse ratio $\left(r_{\mathrm{d}}\right)$ and direct ratio $\left(1-r_{\mathrm{d}}\right)$, respectively:

$\alpha=\left(1-r_{\mathrm{d}}\right) \cdot \alpha_{\mathrm{BSA}}+r_{\mathrm{d}} \cdot \alpha_{\mathrm{WSA}}$.

$r_{\mathrm{d}}$ was obtained from an exponential fit of Eq. (21) based on empirical observations (Roesch, 2004; Stokes and Schwartz, 1994):

$r_{\mathrm{d}}=0.122+0.85 e^{-4.8 \mu_{0}}$,

where $\mu_{0}$ is the cosine of the zenith angle, which is calculated by the model for any specified date, time, and latitude and longitude of the site. The surface-based aerosol optical properties, including the aerosol light absorption coefficients of both $\mathrm{BC}$ and $\mathrm{BrC}$, i.e., differentiated from each other under the assumption of uniform $\mathrm{AAE}_{\mathrm{BC}}$, along with the nephelometer-measured aerosol scattering coefficients, were used to calculate the SSA at different wavelengths according to Eq. (22):

$\operatorname{SSA}(\lambda)=\frac{\sigma_{\mathrm{scat}, \lambda}}{\sigma_{\mathrm{abs}, \mathrm{BrC}, \lambda}+\sigma_{\mathrm{abs}, \mathrm{BC}, \lambda}+\sigma_{\mathrm{scat}, \lambda}}$.
This was then used in the model calculation. Finally, the AOD and asymmetry factor (ASY) at 440, 675, and $870 \mathrm{~nm}$ were derived from the Aerosol Robotic Network (AERONET) measurements at the Hong Kong Polytechnic University site (Holben et al., 1998), which is approximately $115 \mathrm{~km}$ to the southeast of the Panyu site. The tropical atmospheric profile was used in the SBDART model based on the prevailing weather conditions in the PRD. The aerosol DRF $(\Delta F)$ was calculated as the difference between the downward and upward radiation fluxes:

$\Delta F=F \downarrow-F \uparrow$.

\section{Results and discussion}

\subsection{Aerosol light absorption}

The $\mathrm{AAE}_{\mathrm{BC}}$ is widely defined as the uniform representation of the wavelength dependence of a $\mathrm{BC}$ particle (Olson et al., $2015)$. In reality, $A A E_{B C}$ may vary significantly with $B C-$ containing aerosols of different sizes, mixing states, and morphologies (Lack and Langridge, 2013; Scarnato et al., 2013). In fact, some studies showed that the AAE of a large size, pure BC core may be less than 1.0 (Liu et al., 2018) and that the AAE of BC coated with a non-absorbing shell may be larger than that under uniformity (Lack and Cappa, 2010).

It has been suggested that a significant fraction of smaller size particles is non-BC-containing (Cheung et al., 2016; Ma et al., 2017). BC and non-BC materials can also be externally or internally mixed. Although size-resolved BC measurements were not available during this work, we conducted size-resolved V-TDMA measurements at $300{ }^{\circ} \mathrm{C}$ for 40,80 , $110,150,200$, and $300 \mathrm{~nm}$ during an earlier field campaign (February 2014) at the same site as in this work. At $300^{\circ} \mathrm{C}$, all non-BC particles will be completely vaporized (CV), and thus the portion of non-BC particles at such size, denoted as $\Phi_{N, \mathrm{CV}}$, can be determined. The average $\Phi_{N, \mathrm{CV}}$ values were $0.384,0.181,0.180,0.158,0.143$, and 0.137 , corresponding to $40,80,110,150,200$, and $300 \mathrm{~nm}$ (see Fig. S3), respectively (Cheung et al., 2016; Tan et al., 2016a). The $\Phi_{N, \mathrm{CV}}$ values for other sizes were interpolated linearly from these six diameters. For particle sizes larger than $300 \mathrm{~nm}$ and less than $40 \mathrm{~nm}, \Phi_{N, \mathrm{CV}}$ values were set to 0.137 and 0.384 , respectively. Accordingly, the complete distribution of $\Phi_{N, \mathrm{CV}}$ for the whole PNSD was obtained. The mixing states of BC particles were also estimated here, i.e., the mass portion of externally mixed $\mathrm{BC}$ with respect to total $\mathrm{BC}$, denoted as $r_{\mathrm{ext}}$. The value of $r_{\mathrm{ext}}$ was taken as 0.58 , which was obtained using an optical closure method during a previous field experiment at this site (Tan et al., 2016a). During the following Mie theory calculation, a fixed refractive index $\left(\widetilde{m}_{\text {core }}=1.80\right.$ $\left.0.54 i, \widetilde{m}_{\text {non }}=1.55-10^{-7} i\right)$ was adopted for the whole size range. Accordingly, the calculated $\mathrm{BC}$ absorption at $880 \mathrm{~nm}$ $\left(\mathrm{Abs}_{880}\right.$ ) was $21.869 \mathrm{Mm}^{-1}$, which is reasonably close to the measured mean value of $21.199 \mathrm{Mm}^{-1}$. To further validate 
Table 1. Intercomparison of the performance of various Mie-calculation schemes. Base Case is based on the empirical distribution function and mixing states of BC particles obtained from previous field measurements at the same site. $\Phi_{N, \mathrm{CV}}$ denotes the portion of non-BC particles, and $r_{\text {ext }}$ is the mass portion of externally mixed $\mathrm{BC}$ with respect to total $\mathrm{BC}$. AAE $\mathrm{BC}_{\mathrm{BC}}$ is the absorption Ångström exponent of $\mathrm{BC}$, and the subscript represents the wavelength range. $\mathrm{Abs}_{\mathrm{BrC}, 370} \%$ and $\mathrm{Abs}_{\mathrm{BrC}, 520} \%$ are the $\mathrm{BrC}$ absorption contributions at 370 and $520 \mathrm{~nm}$, respectively. Calcabs 880 is the calculated absorption at $880 \mathrm{~nm}$ using the Mie model. Measabs 880 is the measured absorption by an Aethalometer at $880 \mathrm{~nm} . b$ is the intercept of the regression analysis between Measabs 880 and Calcabs880, i.e., Calcabs880 $=b *$ Measabs 880 . $R^{2}$ is the correlation coefficient of the equation. The refractive index of BC core $\left(\widetilde{m}_{\text {core }}\right)$ and non-light-absorbing particles $\left(\widetilde{m}_{\text {non }}\right)$ is set to be $1.80-0.54 i$ and $1.55-10^{-7} i$, respectively (Tan et al., 2016a).

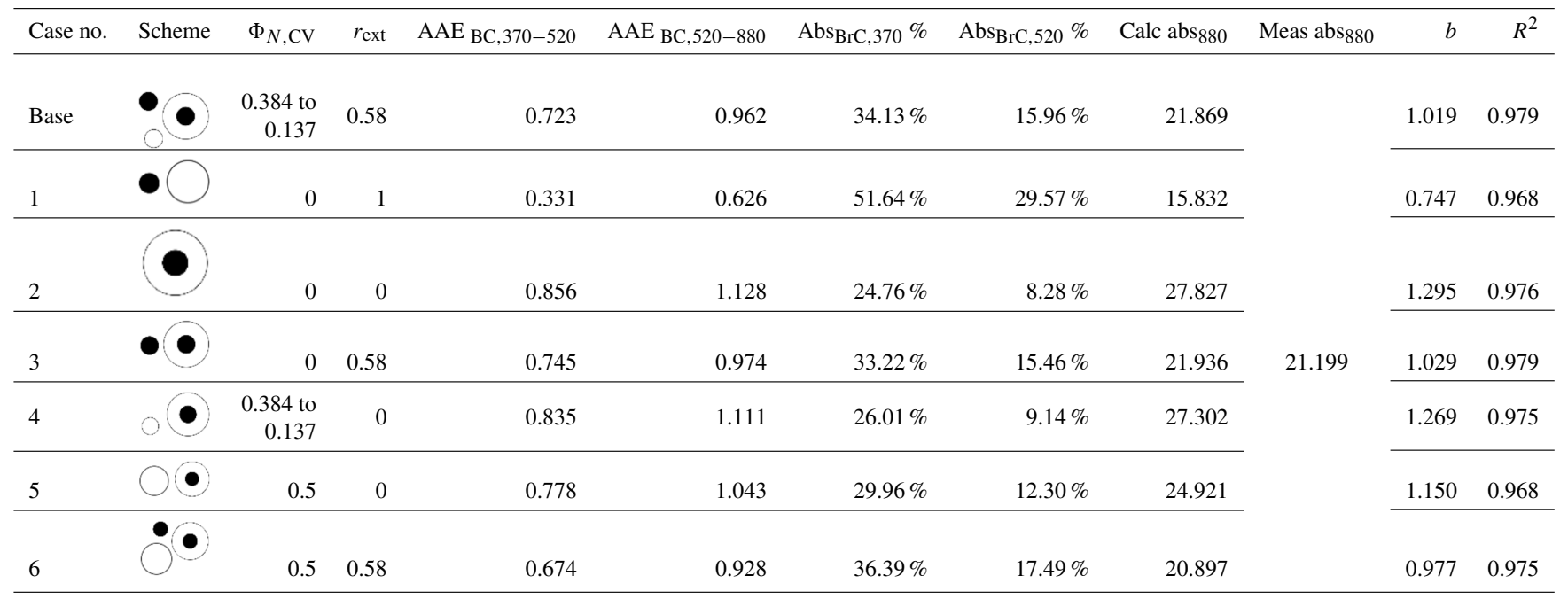

our calculation scheme (Base Case), we have considered several extreme cases.

Case 1: $\mathrm{BC}$ is completely externally mixed with non-BC particles, i.e., $\Phi_{N, \mathrm{CV}}=0$ and $r_{\mathrm{ext}}=1$;

Case 2: $\mathrm{BC}$ is present in every size bin and $\mathrm{BC}$ is completely internally mixed with non-BC material, i.e., $\Phi_{N, \mathrm{CV}}=0$ and $r_{\mathrm{ext}}=0$;

Case 3: BC is both internally and externally mixed, but there are no non-BC-containing particles, i.e., $\Phi_{N, \mathrm{CV}}=$ 0 and $r_{\mathrm{ext}}=0.58$;

Case 4: $\mathrm{BC}$ is internally mixed with non-BC material and there are non-BC particles present, i.e., $\Phi_{N, \mathrm{CV}}$ ranges from 0.384 to 0.137 and $r_{\mathrm{ext}}=0$;

Case 5: the same as Case 4 except assuming a fixed non$\mathrm{BC}$ to $\mathrm{BC}$ ratio of 0.5 , i.e., $\Phi_{N, \mathrm{CV}}=0.5, r_{\mathrm{ext}}=0$;

Case 6: the same as Case 5 except that some externally mixed BC is also present, i.e., $\Phi_{N, \mathrm{CV}}=0.5, r_{\mathrm{ext}}=0.58$.

The calculation results are listed in Table 1. Evidently, Case 1 (completely externally mixed) will significantly underestimate the measured $\mathrm{Abs}_{880}$, indicating that most $\mathrm{BC}$ particles were not likely externally mixed at the Panyu site. The complete internal mixing state (Cases 2, 4, and 5), by contrast, would substantially overestimate the $\mathrm{BC}$ absorption regardless of the form of the $\mathrm{BC}$ core distribution function. However, when the $r_{\text {ext }}$ was considered (Base Case, Case 3, and
Case 6), the calculated $\mathrm{Abs}_{880}$ values were all very close to the measured value, especially the Base Case.

When the $\mathrm{AAE}_{\mathrm{BC}}$ was assumed to be uniform, the campaign-averaged $\sigma_{\mathrm{BrC}}$ values were $17.6 \pm 13.7 \mathrm{Mm}^{-1}$ at $370 \mathrm{~nm}, 9.7 \pm 7.9 \mathrm{Mm}^{-1}$ at $470 \mathrm{~nm}, 5.8 \pm 5.1 \mathrm{Mm}^{-1}$ at $520 \mathrm{~nm}, 4.0 \pm 3.5 \mathrm{Mm}^{-1}$ at $590 \mathrm{~nm}$, and $2.3 \pm 2.1 \mathrm{Mm}^{-1}$ at $660 \mathrm{~nm}$. At the corresponding wavelengths, $\mathrm{BrC}$ absorption contributed $26.2 \% \pm 8.5 \%, 20.0 \% \pm 7.3 \%$, $14.3 \% \pm 6.5 \%, 11.7 \% \pm 5.3 \%$, and $7.8 \% \pm 4.1 \%$ to the total aerosol absorptions. When the $\mathrm{AAE}_{\mathrm{BC}}$ was applied as the result of the Mie model calculation, the corrected campaign-averaged $\sigma_{\mathrm{abs}, \mathrm{BrC}}$ values were $23.5 \pm 17.7 \mathrm{Mm}^{-1}$ at $370 \mathrm{~nm}, 11.8 \pm 9.5 \mathrm{Mm}^{-1}$ at $470 \mathrm{~nm}, 6.7 \pm 5.7 \mathrm{Mm}^{-1}$ at $520 \mathrm{~nm}, 4.6 \pm 3.9 \mathrm{Mm}^{-1}$ at $590 \mathrm{~nm}$, and $2.6 \pm 2.3 \mathrm{Mm}^{-1}$ at $660 \mathrm{~nm}$. At the corresponding wavelengths, $\mathrm{BrC}$ absorption contributed $34.1 \% \pm 8.0 \%, 23.7 \% \pm 7.3 \%$, $16.0 \% \pm 6.7 \%, 13.0 \% \pm 5.4 \%$, and $8.7 \% \pm 4.3 \%$ to the total aerosol absorption (see Fig. 2). Evidently, aerosol light absorption was predominantly due to $\mathrm{BC}$; however, $\mathrm{BrC}$ also played a significant role, especially at shorter wavelengths. Table 2 shows the intercomparison of $\mathrm{BrC}$ light absorption in the near UV range between this work and other studies in the East Asian region. Clearly, the reported values vary substantially, and our result is toward the lower end of values. Figure S4 displays the time series of particle AAE measured by the Aethalometer, and $\mathrm{AAE}_{\mathrm{BC}}$ was derived from Mie model calculation. The $\mathrm{AAE}_{\mathrm{BC}}$ was almost always 


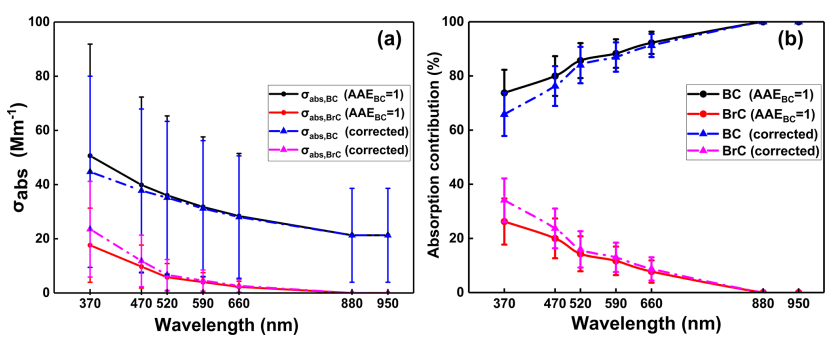

Figure 2. (a) $\mathrm{BC}$ and $\mathrm{BrC}$ particle average light absorption coefficients at different wavelengths under different $\mathrm{AAE}_{\mathrm{BC}}$ assumptions; the whiskers represent an error of 1 standard deviation. (b) Contributions of $\mathrm{BC}$ and $\mathrm{BrC}$ to the total light absorption coefficient at different wavelengths under different $\mathrm{AAE}_{\mathrm{BC}}$ assumptions; the whiskers represent an error of 1 standard deviation.

lower than AAE, indicating appreciable BrC light absorption at the Panyu site.

\subsection{Uncertainty in $\mathrm{BC}$ and $\mathrm{BrC}$ optical differentiation}

Theoretically, the magnitude of $\mathrm{BC}$ absorptions can be affected by both parts of the complex RIs; thus, $\mathrm{AAE}_{\mathrm{BC}}$ may also vary with the RIs of both the BC core and coating shell. In fact, RI was also one of the least known properties of $\mathrm{BC}$ and other coating materials with negligible absorbing capabilities. The refractive index of the BC core $\left(\widetilde{m}_{\text {core }}\right)$ displays a wide range of variations (Liu et al., 2018). Typically, the real and imaginary parts of the RI can vary from 1.5 to 2.0 and 0.5 to 1.1 , respectively. In addition, the shell was assumed to consist of non-absorbing material in the core-shell model; i.e., its imaginary RI was set to be close to zero $\left(10^{-7}\right)$. The real part of the non-absorbing material RI ( $\left.\tilde{m}_{\text {non }}\right)$ may vary from 1.35 to 1.6 due to the presence of OA (Redmond and Thompson, 2011; Zhang et al., 2018) and inorganic salts (Erlick et al., 2011). Hence, it is necessary to investigate the uncertainties associated with the variations in $\mathrm{AAE}_{\mathrm{BC}}$ by varying the RIs of both the $\mathrm{BC}$ core and the non-absorbing materials.

Figure 3 shows the impacts of RI on the evaluations of $\mathrm{AAE}_{\mathrm{BC}}$ based on core-shell and external configuration, where the RI of the BC core was set to be constant, i.e., $\widetilde{m}_{\text {core }}=1.80-0.54 i$, and the real part of $\widetilde{m}_{\text {non }}$ varied from 1.35 to 1.6 at an interval of 0.05 , with the imaginary part of $\widetilde{m}_{\text {non }}$ set at $10^{-7}$. As shown in Fig. 3a, the calculated AAE $\mathrm{BC}_{\mathrm{BC}}$ for the core-shell model was higher than 1.0 at longer wavelengths $(520$ to $880 \mathrm{~nm})$ and lower than 1.0 at shorter wavelengths ( 370 to $520 \mathrm{~nm}$ ) (the red line in Fig. 3 denotes

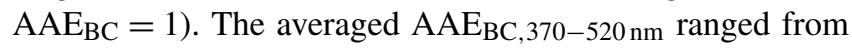

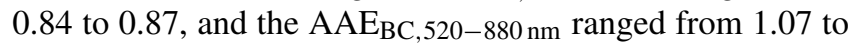

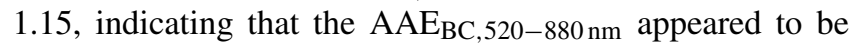

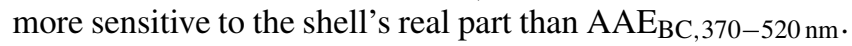
Even if the shell material was assumed to be non-absorbing, the variation in the real RI of the shell, which was referred to as the real part of $\widetilde{m}_{\text {non }}$, still led to changes in the shell's refractivity and correspondingly altered its lensing effect, caus- ing a change in $\mathrm{AAE}_{\mathrm{BC}}$. Meanwhile, $\mathrm{AAE}_{\mathrm{BC}, 370-520 \mathrm{~nm}}$ and

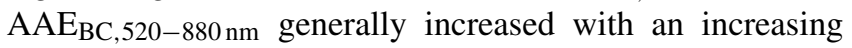
real part of the shell. In Fig. 3b, under the externally mixed

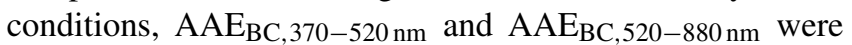

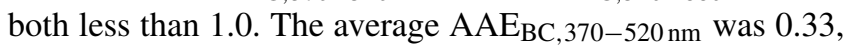
and the average $A A E_{B C, 520-880 n m}$ was 0.63 . These values were far less than the values under core-shell mixture conditions. In the external mixture model, the BC core and nonlight-absorbing materials were assumed to exist dependently, and then the optical properties of these two components were considered separately. Therefore, altering the real part of the externally mixed non-absorbing material would not affect the light absorption property of the $\mathrm{BC}$ core or $\mathrm{AAE}_{\mathrm{BC}}$.

The impacts of the $\mathrm{BC}$ core on $\mathrm{AAE}_{\mathrm{BC}}$ are shown in Fig. 4, where the refractive index of non-light-absorbing materials was assumed to be $\widetilde{m}_{\text {non }}=1.5510^{-7} i$ and $\widetilde{m}_{\text {non }}$ was wavelength-independent. Figure 4 was obtained with a coreshell mixture model (Fig. 4a and b) and an external mixture model (Fig. $4 \mathrm{c}$ and d) by varying the real part of $\widetilde{m}_{\text {core }}$ from 1.5 to 2.0 with a step of 0.05 and varying the imaginary part of the $\widetilde{m}_{\text {core }}$ from 0.4 to 1.0 with a step of 0.05 . As shown in Fig. 4a and b, for the core-shell mixture, the averaged

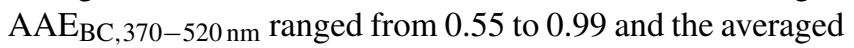

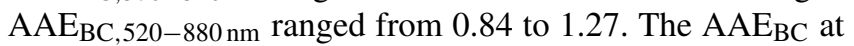
a certain wavelength generally increased when increasing the real part of $\widetilde{m}_{\text {core }}$ but decreased when increasing the imaginary part of $\widetilde{m}_{\text {core }}$. The AAE $\mathrm{BC}$ appeared to be more sensitive to the imaginary part of $\widetilde{m}_{\text {core }}$ than the real part of $\widetilde{m}_{\text {core }}$ because the imaginary part of $\widetilde{m}_{\text {core }}$ was directly related to the light-absorbing properties of particles. In Fig. $4 \mathrm{c}$ and d, for the external mixture, the averaged $\mathrm{AAE}_{\mathrm{BC}, 370-520 \mathrm{~nm} \text { ranged }}$

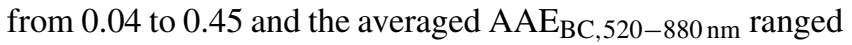
from 0.28 to 0.79 , while the averaged $\mathrm{AAE}_{\mathrm{BC}, 370-520 \mathrm{~nm} \text { and }}$

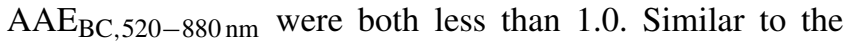

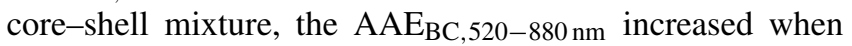
increasing the real part of $\widetilde{m}_{\text {core }}$ but decreased when increasing the imaginary part of $\widetilde{m}_{\text {core }}$. However, the variation patterns of $A A E_{B C, 370-520 n m}$ were different from those of

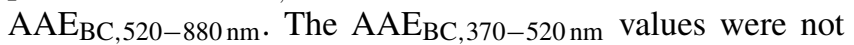
changed by altering the real part of $\widetilde{m}_{\text {core }}$ within the low imaginary part of $\widetilde{m}_{\text {core }}$, whereas the $\mathrm{AAE}_{\mathrm{BC}, 370-520 \mathrm{~nm}}$ values still increased when increasing the real part of $\widetilde{m}_{\text {core }}$ within the high imaginary part of $\widetilde{m}_{\text {core }}$. A possible explanation was that the externally mixed $\mathrm{BC}$ core had weak light absorption within the low imaginary part of $\widetilde{m}_{\text {core }}$, causing the $\mathrm{AAE}_{\mathrm{BC}, 370-520 \mathrm{~nm}}$ values to be insensitive to the real part

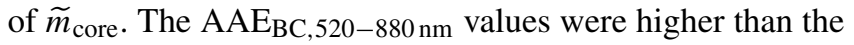

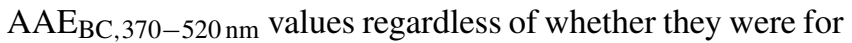
the core-shell mixture or the external mixture. In addition, the $\mathrm{AAE}_{\mathrm{BC}}$ values conducted by the core-shell mixture were higher than those conducted by the external mixture.

Figure 4 demonstrated that the variation in the imaginary $\mathrm{RI}$ of the $\mathrm{BC}$ core had the most significant impact on the estimated $\mathrm{AAE}_{\mathrm{BC}}$, indicating that the chemical component of $\mathrm{BC}$ emitted from different sources led to a large uncertainty 
Table 2. Observational studies of the BrC light absorption coefficient and contribution in the near-ultraviolet wavelength range in East Asia.

\begin{tabular}{|c|c|c|c|c|c|c|}
\hline Periods & Location & $\begin{array}{r}\lambda \\
(\mathrm{nm})\end{array}$ & $\begin{array}{l}\text { Mean BrC } \\
\text { absorption } \\
\text { coefficient }\end{array}$ & $\begin{array}{l}\text { Mean BrC } \\
\text { absorption } \\
\text { contribution }\end{array}$ & Instrumentation & Reference \\
\hline Nov 2014-Jan 2015 & Guangzhou (China) & 370 & $\begin{array}{l}17.6 \mathrm{Mm}^{-1} \\
23.5 \mathrm{Mm}^{-1}\end{array}$ & $\begin{array}{l}26.2 \%\left(\mathrm{AAE}_{\mathrm{BC}}=1\right) \\
34.1 \%(\text { corrected })\end{array}$ & $\begin{array}{l}\text { Aethalometer } \\
\text { AE-33 }\end{array}$ & This study \\
\hline $\begin{array}{l}\text { Jan 2014-Feb 2014; } \\
\text { Sep 2014-Oct } 2014\end{array}$ & Shenzhen (China) & 405 & $\begin{array}{l}3.0 \mathrm{Mm}^{-1} \\
1.4 \mathrm{Mm}^{-1}\end{array}$ & $\begin{array}{l}11.7 \% \text { (winter) } \\
6.3 \% \text { (fall) }\end{array}$ & PASS-3 & Yuan et al. (2016) \\
\hline Nov 2014 & (China) & 405 & $3.9 \mathrm{Mm}^{-1}$ & $12.1 \%$ & PASS-3 & Yuan et al. (2016) \\
\hline Nov 2016-Dec 2016 & (China) & 370 & $\begin{array}{l}106.4 \mathrm{Mm}^{-1} \\
93.8 \mathrm{Mm}^{-1}\end{array}$ & $\begin{array}{l}46 \% \text { (at the ground) } \\
48 \% \text { (at } 260 \mathrm{~m} \text { ) }\end{array}$ & $\begin{array}{l}\text { Aethalometer } \\
\text { AE-33 }\end{array}$ & Xie et al. (2018) \\
\hline Jun 2013-May 2016 & Nanjing (China) & 370 & $35.8 \mathrm{Mm}^{-1}$ & $16.7 \%$ & Aethalometer AE-31 & Wang et al. (2018) \\
\hline Jan 2012 & Nagoya (Japan) & 405 & Not detected & $\begin{array}{l}11 \%\left(300^{\circ} \mathrm{C}\right) \\
17 \%\left(400^{\circ} \mathrm{C}\right)\end{array}$ & $\begin{array}{l}\text { Thermodenuder } \\
\text { PASS-3 }\end{array}$ & $\begin{array}{l}\text { Nakayama et } \\
\text { al. (2015) }\end{array}$ \\
\hline
\end{tabular}
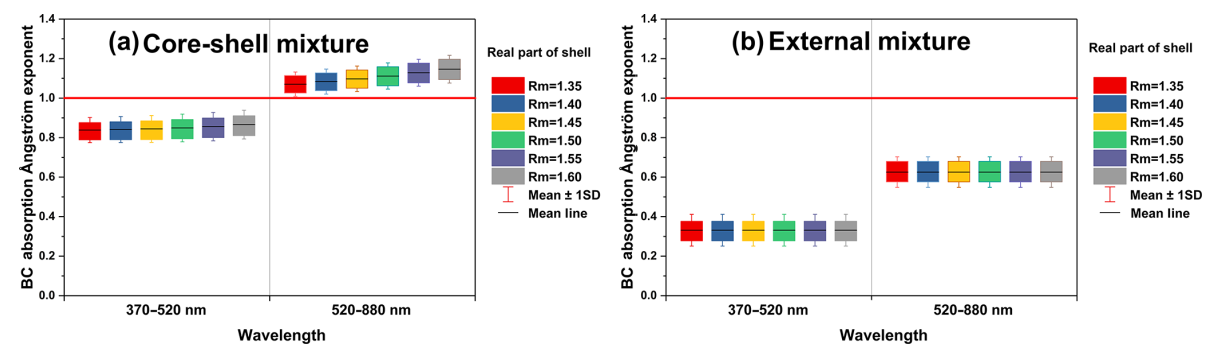

Figure 3. Influence of the wavelength-independent refractive index of the non-absorbing materials on the (a) AAEs of the core-shell mixture and (b) AAEs of the external mixture with a constant BC core refractive index $\left(\widetilde{m}_{\text {core }}=1.80-0.54 i\right)$. The imaginary part of the non(less)absorbing shell was set to $10^{-7}$, while the real part varied from 1.35 to 1.60 . In each panel, the boundaries of the box represent the 75 th and 25th percentiles; the whiskers above and below each box indicate an error of 1 standard deviation; the black lines in the boxes denote the average values. In panels (a) and (b), the red line indicates where $\mathrm{AAE}_{\mathrm{BC}}=1$.

in $\mathrm{AAE}_{\mathrm{BC}}$ estimation. At the same time, the influence arising from varying the real RI of the $\mathrm{BC}$ core was relatively moderate. Nevertheless, Fig. 3 shows that change in the real RI of the non-absorbing materials caused the least or no impact compared to the variations in the complex $\mathrm{RI}$ of the $\mathrm{BC}$ core.

It should be pointed out that most $\mathrm{BC}$-containing particles are often observed as being fractal rather than spherical in shape (Katrinak et al., 1993). Because the Mie model assumes that all particles are spherical, it may lead to potential uncertainty for the estimation of $\mathrm{AAE}_{\mathrm{BC}}$ and $\mathrm{BrC}$ absorption contributions. Moreover, the externally mixed soot aggregates were "chain-like" or "puff-like" in the PRD dry season (Feng et al., 2010), in which the fractal dimension $\left(D_{\mathrm{f}}\right)$ was between 1.5 and 2.0. Coating soot aggregates were likely spheres $\left(D_{\mathrm{f}}\right.$ approaches 3$)$ from the high-resolution transmission electron microscopy (TEM) measurements taken in Hong Kong (Zhou et al., 2014). A soot aggregate sensitivity study with the superposition T-matrix method indicated that using the assumption of volume-equivalent spheres for the soot aggregates may result in an overestimation of approximately up to $15 \%$ and an underestimation of approximately up to $50 \%$ in the predicted $870 \mathrm{~nm}$ light absorption when the $D_{\mathrm{f}}$ is between 1.5 and 3.0 (Liu et al., 2008). However, it should be recognized that the complex shapes or positions of the $\mathrm{BC}$ core inside the particle make it impractical to be numerically simulated in the exact details. By far the Mie model with a core-shell configuration would be the most practical and effective simulation scheme for BC particle optical property simulation.

Furthermore, we have performed Monte Carlo simulations to evaluate the uncertainties of the Mie calculation performed during this work. In the simulation, a sequence of random numbers or errors were applied to the input parameters, and then the corresponding uncertainties of particle light absorption and $\mathrm{AAE}_{\mathrm{BC}}$ were computed using the Mie model. Five hundred reiterations were conducted during the simulation such that the random errors will be normally distributed. The standard deviations $(\sigma)$ of all input parameters are listed in Table S1. In order to cover the effect of extreme value, we used a range of $\pm 3 \sigma$, or a confidence level of $99 \%$, in the Monte Carlo simulation. Table S2 lists the Monte Carlo simulation results, i.e., the average relative stan- 

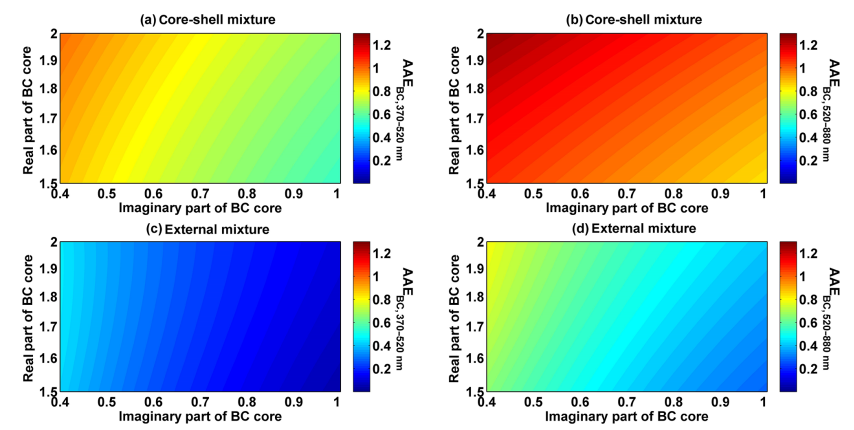

Figure 4. Influence of the wavelength-independent refractive index of the BC core on AAEs with a constant shell refractive index $\left(\tilde{m}_{\text {shell }}=1.55-10^{-7} i\right)$. A core-shell mixture was used for panels $\mathrm{a}$ and $\mathrm{b}$, and an external mixture was used for panels $\mathrm{c}$ and $\mathrm{d}$. The

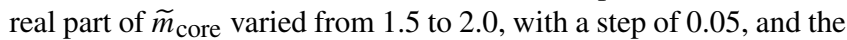

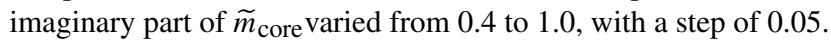

dard deviations $\left(\sigma_{\mathrm{Mie}}\right)$ of the calculated $\mathrm{BC}$ light absorption at $880 \mathrm{~nm}\left(\mathrm{Abs}_{880}\right), \mathrm{AAE}_{\mathrm{BC}, 370-520}$, and $\mathrm{AAE}_{\mathrm{BC}, 520-880}$.

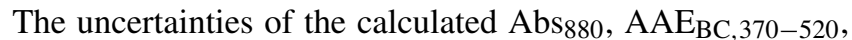
and $\mathrm{AAE}_{\mathrm{BC}, 520-880}$ at two times of $\sigma_{\mathrm{Mie}}$, i.e., at a confidence level of $95 \%$, were approximately $\pm 31 \%, \pm 16 \%$, and $\pm 13 \%$, respectively. Figure S5a shows the time series of the

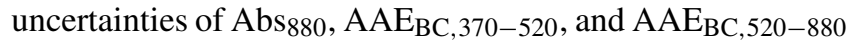
from a Monte Carlo simulation for the campaign period. These uncertainties will certainly be propagated into the calculated $\mathrm{BrC}$ absorption contributions, too. Hence, we also estimated the corresponding uncertainties in the $\mathrm{BrC}$ absorption contribution results, as shown in Fig. S5b. Accordingly, the averaged lower limits of $\mathrm{BrC}$ absorption contributions were $26.8 \% \pm 9.1 \%$ at $370 \mathrm{~nm}, 17.5 \% \pm 8.1 \%$ at $470 \mathrm{~nm}, 10.1 \% \pm 7.3 \%$ at $520 \mathrm{~nm}, 8.5 \% \pm 5.8 \%$ at $590 \mathrm{~nm}$, and $5.3 \% \pm 4.5 \%$ at $660 \mathrm{~nm}$, and the averaged upper limits of $\mathrm{BrC}$ absorption contribution ratios were $40.7 \% \pm 7.2 \%$ at $370 \mathrm{~nm}, 29.5 \% \pm 6.7 \%$ at $470 \mathrm{~nm}, 21.1 \% \pm 6.2 \%$ at $520 \mathrm{~nm}, 17.3 \% \pm 5.2 \%$ at $590 \mathrm{~nm}$, and $12.0 \% \pm 4.1 \%$ at $660 \mathrm{~nm}$.

\subsection{Characteristics of $\mathrm{BrC}$ light absorption, water-soluble ions, and $\mathrm{OC}$ concentrations}

Globally, $\mathrm{BrC}$ has been observed to be highly correlated with biomass and biofuel burning emissions (Laskin et al., 2015). Since large quantities of sylvite are present in biomass burning particles, the $\mathrm{K}^{+}$abundance has often been used as a biomass burning tracer (Levine, 1991). Figure 5 presents the time series of the $\mathrm{OC}$ mass concentration, $\mathrm{K}^{+}$concentration, and BrC absorption from 29 November 2014 to 2 January 2015 at the Panyu site. The range of the OC concentrations obtained from the OC/EC online analyzer was from 1.5 to $65.2 \mu \mathrm{g} \mathrm{cm}^{-3}$, and the campaign average was $12.5 \pm 7.3 \mu \mathrm{g} \mathrm{cm}^{-3}$. The BrC absorption hourly mean data were between 0.2 and $123.2 \mathrm{Mm}^{-1}$, and the campaign average was $23.5 \pm 17.7 \mathrm{Mm}^{-1}$. On the other hand, the aver-

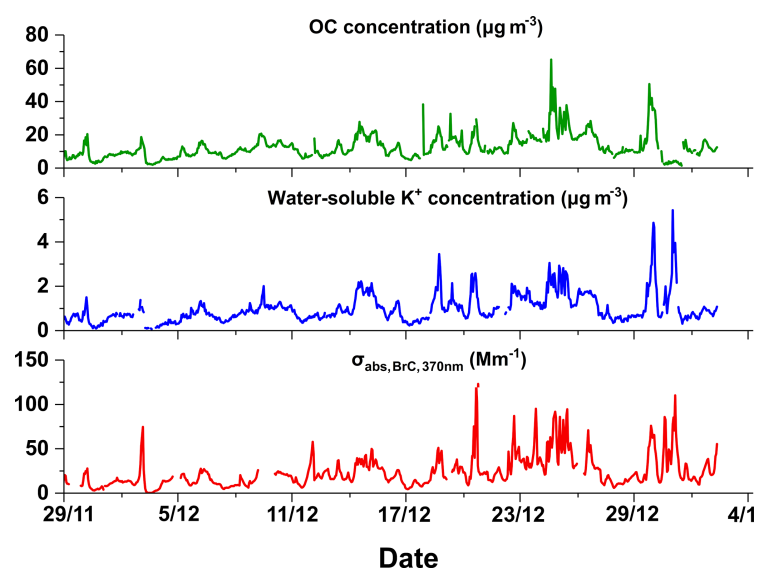

Figure 5. Time series of the $\mathrm{OC}$ aerosol mass concentration (green line), water-soluble $\mathrm{K}^{+}$mass concentration (blue line), and $\mathrm{BrC}$ light absorption (red line).

age $\mathrm{K}^{+}$concentration was $1.0 \pm 0.7 \mu \mathrm{g} \mathrm{cm}^{-3}$ (ranging from 0 to $5.4 \mu \mathrm{g} \mathrm{cm}^{-3}$ ). Clearly, similar trends among OC, $\mathrm{K}^{+}$, and $\mathrm{BrC}$ absorption can be seen during this field campaign (Fig. 5).

To investigate the origins of these observed $\mathrm{OC}, \mathrm{K}^{+}$, and $\mathrm{BrC}$, wind rose plots (as shown in Fig. 6) were generated for $\mathrm{OC}, \mathrm{K}^{+}$, and $\mathrm{BrC}$ absorption, respectively. All three panels of Fig. 6 consistently show that the three substances were associated with the same wind pattern. For the entire campaign period, the highest values of $\mathrm{OC}, \mathrm{K}^{+}$, and $\sigma_{\mathrm{abs}, \mathrm{BrC}, 370 \mathrm{~nm}}$ were mostly associated with southwesterly winds with a relatively low wind speed $\left(\sim 2 \mathrm{~m} \mathrm{~s}^{-1}\right)$. The relatively higher OC and $\mathrm{K}^{+}$concentrations were highly related to the seasonal straw burning in the countryside of the PRD located to the west of the Panyu station. In contrast, $\mathrm{OC}$ and $\mathrm{K}^{+}$concentrations during periods with easterly winds were substantially lower than those during periods with westerly winds. The

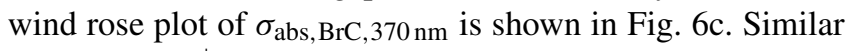

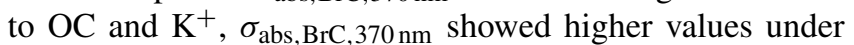
weak $\left(<2 \mathrm{~m} \mathrm{~s}^{-1}\right)$ westerly winds and lower values from the north and south, indicating that $\mathrm{BrC}$ absorption was likely attributed to local sources and was accumulated under calm wind conditions. Figure $\mathrm{S} 6$ shows the $3 \mathrm{~d}$ backward trajectory and the fire counts for 5 to 7 (Fig. S6a), 12 to 14 (Fig. S6b), and 24 to 26 (Fig. S6c) in November 2014, representing lowloading, moderate-loading, and high-loading period. Clearly, the high-loading period concurred with stagnant air movement and higher fire counts, indicating the contribution from open fire burning sources. However, there was a detectable difference among the three rose plots of Fig. 6 in the maximum concentration direction. A possible explanation was that although biomass burning emissions were believed to be the dominant and primary source of $\mathrm{OC}, \mathrm{K}^{+}$, and $\mathrm{BrC}$, their emission ratios were highly variable and may change with the type of biofuel and burning condition and may even vary during different stages of burning (Burling et al., 2012). Al- 

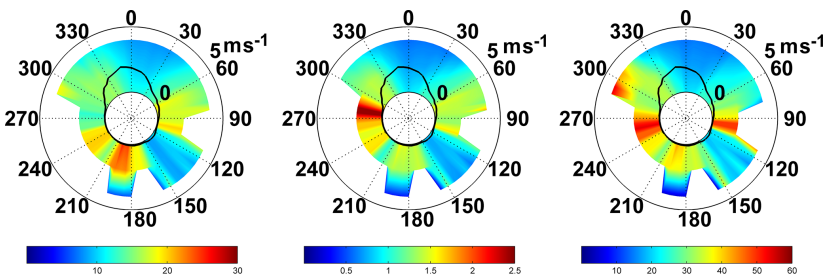

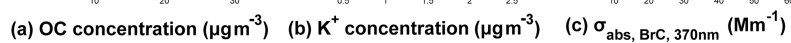

Figure 6. Wind rose plots of $\mathrm{OC}(\mathbf{a}), \mathrm{K}^{+}(\mathbf{b})$, and $\sigma_{\mathrm{abs}, \mathrm{BrC}, 370 \mathrm{~nm}}$ (c). In each panel, the black solid lines denote the frequency of the wind direction. The shaded contour represents the average values of the corresponding species for that wind speed (radial length) and wind direction (transverse direction) in polar coordinates.

though biomass burning emissions contain substantial lightabsorbing $\mathrm{BrC}$, further atmospheric aging processes may significantly reduce its light-absorbing capability (Satish et al., 2017). Moreover, secondary formation may also lead to BrC formation inside these primary aerosols, such as humic-like substances formed through aqueous-phase reactions, which have been suggested to be an important component of $\mathrm{BrC}$ (Andreae and Gelencser, 2006).

To further explore the possible sources of $\mathrm{BrC}$ optical absorption, the diurnal variations in $\mathrm{OC}, \mathrm{K}^{+}, \sigma_{\mathrm{abs}, \mathrm{BrC}, 370 \mathrm{~nm}}$, and $\sigma_{\mathrm{abs}, \mathrm{BrC}, 370 \mathrm{~nm}} / \mathrm{OC}$ values are plotted in Fig. 7. The diurnal variation in OC at the Panyu site appeared to be dominated by the development of the planetary boundary layer (PBL) height; i.e., primary emissions accumulated at night and were swiftly diluted by vertical mixing in the morning. The slight increase in OC in the afternoon indicated that photochemistry may have still weakly contributed to SOA formation. Figure $7 \mathrm{~b}$ shows the diurnal variation in $\mathrm{K}^{+}$. Unlike $\mathrm{OC}, \mathrm{K}^{+}$shows a small peak at approximately 06:00, which was consistent with breakfast time and was very likely due to cooking activities using biofuel. No lunch and dinnertime $\mathrm{K}^{+}$peaks were observed. The most likely explanation is that the boundary layer height is much higher during lunch and dinnertime than in the early morning, providing a much better atmospheric diffusion condition for air pollutants. It is still a common practice to collect straw as biofuel in local rural areas, which can be visually spotted but is not heavily utilized in the region. However, the diurnal pro-

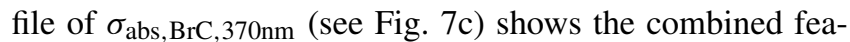
tures of $\mathrm{OC}$ and $\mathrm{K}^{+}$since both primary and secondary processes affect its intensity. The nighttime increasing trend was most likely attributed to straw burning activities in early winter in nearby rural areas that continued to accumulate within the shallow PBL (Jiang et al., 2013). $\sigma_{\mathrm{abs}, \mathrm{BrC}, 370 \mathrm{~nm}} / \mathrm{OC}$, i.e., the mass absorption coefficient of $\mathrm{BrC}\left(\mathrm{MAC}_{\mathrm{BrC}}\right)$ (Fig. 7d), showed a relatively flat pattern, with a pronounced dip in the afternoon and higher values at nighttime, which was likely due to enhanced primary emissions and stable stratification at nighttime. Declining trends during the late morning and afternoon hours indicated that the aging process and photo-
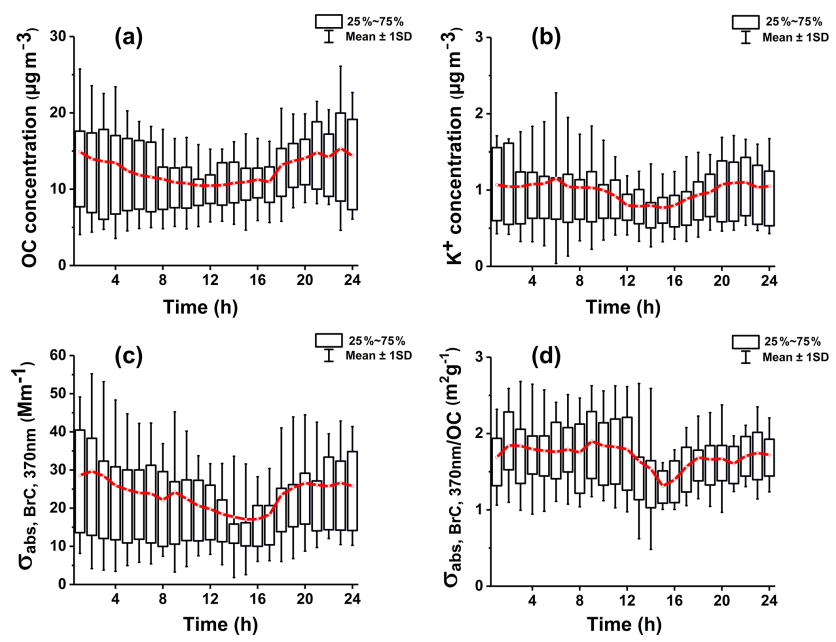

Figure 7. Box-whisker plots of diurnal trends in the OC concentration (a), water-soluble $\mathrm{K}+$ concentration (b), $\sigma_{\mathrm{abs}, \mathrm{BrC}, 370 \mathrm{~nm}}(\mathbf{c})$, and $\sigma_{\mathrm{abs}, \mathrm{BrC}, 370 \mathrm{~nm}} / \mathrm{OC}(\mathbf{d})$. The red traces represent the variation in the average value. The upper and lower boundaries of the box represent the 75th and 25th percentiles, respectively; the whiskers above and below each box represent an error of 1 standard deviation.

chemical production may reduce the light-absorbing capacity of BrC (Qin et al., 2018).

Furthermore, Fig. 8 shows the linear regression analysis results used to evaluate the correlations of $\sigma_{\mathrm{abs}, \mathrm{BrC}, 370 \mathrm{~nm}}$ with the $\mathrm{OC}, \mathrm{K}^{+}, \mathrm{Ca}^{2+}, \mathrm{Mg}^{2+}, \mathrm{Cl}^{-}, \mathrm{SO}_{4}^{2-}, \mathrm{NO}_{3}^{-}$, and $\mathrm{NH}_{4}^{+}$concentrations. The best correlations can be found be-

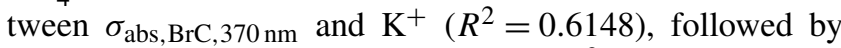

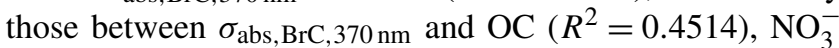
$\left(R^{2}=0.4224\right)$, and $\mathrm{NH}_{4}^{+}\left(R^{2}=0.4656\right)$. Source apportionment analysis of $\mathrm{OA}$ and $\mathrm{BrC}$ absorption in Beijing and Guangzhou illustrated that biomass burning organic aerosols (BBOAs) correlated well with $\mathrm{BrC}$ light absorption (Qin et al., 2018; Xie et al., 2019). Thus, the significant correlation between $\mathrm{BrC}$ absorption and $\mathrm{K}^{+}$reaffirmed that biomass burning was the crucial emission source of $\mathrm{BrC}$ observed in this work. Although the geographic location of the observation site was situated in a coastal area and $\mathrm{K}^{+}$could also be found in sea salt (Pio et al., 2008), it should be noted that the prevailing wind direction during winter was from the north (see Fig. S6), which drives maritime air parcels away from the site. Hence, the effect of sea salt and crustal materials to $\mathrm{K}^{+}$was slight, which was demonstrated in the Supplement as shown in Fig. S7. Other earlier studies also suggested that the sea salt contribution to the $\mathrm{K}^{+}$concentrations of $\mathrm{PM}_{2.5}$ was trivial in the PRD region during the winter (Lai et al., 2007). Another possible $\mathrm{K}^{+}$source was coal combustion. The coal consumption in the PRD region was dominated by coal-fired power plants. The emission from power plants was usually very steady and was less likely to affect the diurnal correlation between $\mathrm{K}^{+}$and $\mathrm{BrC}$ absorption. As shown 
in Fig. S8, the ratios of $\mathrm{K}^{+} / \mathrm{PM}_{2.5}$ vary approximately from 0.015 and 0.020 and the diurnal profile of $\mathrm{K}^{+} / \mathrm{PM}_{2.5}$ shows very little variation. Yu et al. (2018) have suggested that $\mathrm{K}^{+}$ usually accounted for $2.34 \%-5.49 \%$ of $\mathrm{PM}_{2.5}$ in the laboratory biomass burning study. However, $\mathrm{K}^{+}$was normally lower than $1 \%$ of coal combustion $\mathrm{PM}_{2.5}$. Therefore, the ratio range of $\mathrm{K}^{+}$to $\mathrm{PM}_{2.5}$ observed in this work likely indicated aged biomass burning particles. Both nitrogen oxides $\left(\mathrm{NO}_{x}\right)$ and ammonia $\left(\mathrm{NH}_{3}\right)$ can be found in biomass burning plumes (Andreae and Merlet, 2001). For $\mathrm{NO}_{3}^{-}$and $\mathrm{NH}_{4}^{+}$, nitrate can be converted from $\mathrm{NO}_{x}$ through atmospheric reactions, and ammonium may originate from $\mathrm{NH}_{3}$. However, similar to the diurnal variation in $\sigma_{\mathrm{abs}, \mathrm{BrC}, 370 \mathrm{~nm}}$, diurnal variations in $\mathrm{NH}_{4}^{+}$and $\mathrm{NO}_{3}^{-}$also increased in the afternoon and appeared at nighttime in Fig. S8. However, $\mathrm{NO}_{3}^{-} / \mathrm{PM}_{2.5}$ and $\mathrm{NH}_{4}^{+} / \mathrm{PM}_{2.5}$ reached their peaks at noon, indicating that ammonium nitrate formed from the secondary reaction at this time. Along with the reduced boundary layer height and ambient temperature, $\mathrm{NO}_{3}^{-}$was accumulated until the photochemical reaction stopped at night. The diurnal variation in $\mathrm{NH}_{4}^{+}$was similar to that in $\mathrm{NO}_{3}^{-}$due to the acid-base neutralization reaction. The overlapping of the $\sigma_{\mathrm{abs}, \mathrm{BrC}, 370 \mathrm{~nm}}, \mathrm{NH}_{4}^{+}$, and $\mathrm{NO}_{3}^{-}$diurnal variations would lead to a significant correlation between $\mathrm{BrC}$ absorption and $\mathrm{NO}_{3}^{-}$or $\mathrm{NH}_{4}^{+}$. High concentrations of $\mathrm{Ca}^{2+}$ and $\mathrm{Mg}^{2+}$ are often found in dust-related aerosols (Lee et al., 1999). $\sigma_{\mathrm{abs}, \mathrm{BrC}, 370 \mathrm{~nm}}$ showed poor correlations with both $\mathrm{Ca}^{2+}$ and $\mathrm{Mg}^{2+}$, indicating that dustrelated aerosol components contribute insignificantly to the total aerosol mass loading and, thus, dust may not affect the AAE differentiation method used in this work. Although sulfur dioxide $\left(\mathrm{SO}_{2}\right)$ may also be emitted by biomass burning, $\mathrm{SO}_{4}^{2-}$ is often believed to be secondary in nature, and the presence of other intense $\mathrm{SO}_{2}$ sources (e.g., automobile and industrial emissions) further reduces the correlation between $\mathrm{BrC}$ and $\mathrm{SO}_{4}^{2-}$. Sources of $\mathrm{Cl}^{-}$include both combustion and sea salt spray (Waldman et al., 1991). Although the prevailing wintertime wind direction was from the north, sea salt can still be carried to the site by a weak sea breeze, and thus $\mathrm{Cl}^{-}$may not show considerable correlation with $\mathrm{BrC}$.

\subsection{BrC radiative forcing efficiency}

The radiative effects of aerosol scattering, $\mathrm{BrC}$ absorption, and $\mathrm{BC}$ absorption were investigated by the SBDART model. For each investigated variable under cloud-free conditions, we run the model twice to calculate the DRF at the TOA with and without the investigated variable. Accordingly, the difference of $\Delta F$ between the two simulations was considered as the radiative effect of the investigated variable. The results showed that the average radiative forcings at the TOA by scattering, $\mathrm{BrC}$ absorption, and $\mathrm{BC}$ absorption were $-21.4 \pm 5.5 \mathrm{~W} \mathrm{~m}^{-2}, 2.3 \pm 1.8 \mathrm{~W} \mathrm{~m}^{-2}$, and $10.9 \pm 5.1 \mathrm{~W} \mathrm{~m}^{-2}$, respectively. Furthermore, $\mathrm{BrC}$ absorption was attributed to $15.8 \% \pm 4.4 \%$ of the warming effect caused by aerosol light absorption, demonstrating the nonnegligible role of $\mathrm{BrC}$ in radiative forcing evaluation.

We also calculated the $\mathrm{BrC}$ radiative forcing efficiency (RFE) under various SSAs (ranging from 0.70 to 0.99 ) at three wavelengths, i.e., 440,675 , and $870 \mathrm{~nm}$. The RFE was denoted as the radiative forcing normalized by the AOD. The average AOD and ASY at the three wavelengths were 0.365 and 0.691 at $440 \mathrm{~nm}, 0.212$ and 0.632 at $675 \mathrm{~nm}$, and 0.154 and 0.619 at $870 \mathrm{~nm}$. A solar zenith angle of $55^{\circ}$ and an average shortwave broadband surface albedo (0.119) were used in the calculation. The results were plotted as a set of RFE lookup charts as a function of the surface $\mathrm{BrC}$ absorption contribution (see Fig. 9).

In general, for any wavelength, the RFE increased with increasing $\mathrm{BrC}$ absorption contribution for a certain SSA, indicating that $\mathrm{BrC}$ was a more efficient radiative forcing agent due to the preferential absorbance of $\mathrm{BrC}$ in a shorter wavelength range. However, for a certain $\mathrm{BrC}$ absorption contribution, the RFE increased with decreasing SSA; i.e., a higher portion of light-absorbing aerosol components can lead to more efficient radiative forcing. The trend among panels (a), (b), and (c) in Fig. 9 demonstrated that the effect of $\mathrm{BrC}$ absorption contribution on RFE was wavelength-dependent; i.e., $\mathrm{BrC}$ was a weaker radiative forcing agent at longer wavelengths, which is also consistent with the wavelengthdependent light-absorbing property of $\mathrm{BrC}$. The red stars in Fig. 9 denote the average SSA and BrC absorption contribution conditions during this campaign, i.e., $0.029 \mathrm{~W} \mathrm{~m}^{-2}$ per unit AOD at $440 \mathrm{~nm}$ (Fig. 9a), $0.007 \mathrm{~W} \mathrm{~m}^{-2}$ per unit AOD at $675 \mathrm{~nm}$ (Fig. 9b), and $0.0002 \mathrm{~W} \mathrm{~m}^{-2}$ per unit AOD at $870 \mathrm{~nm}$ (Fig. 9c). These results suggested that the average value of RFE decreased distinctly from 440 to $870 \mathrm{~nm}$ not only because of the lower $\mathrm{BrC}$ absorption contribution but also because of the wavelength dependence of the BrC RFE. It should also be noted that the simulations were based on SSA measured under dry conditions. Under the typical ambient conditions of the PRD, the SSA might be markedly enhanced by aerosol water uptake (Jung et al., 2009), and then the $\mathrm{BrC}$ radiative forcing efficiency might be less. Moreover, Fig. 9 also serves as a lookup table to conveniently assess the $\mathrm{BrC}$ radiative forcing efficiency at different wavelengths with different $\mathrm{BrC}$ absorption contributions for a certain SSA.

\section{Conclusions}

In this work, light absorption due to $\mathrm{BrC}$ in the PRD region of China was quantitatively deduced during the winter season of 2014. The AAEs of ambient particles and BC core were derived from the measurements. For ambient particles, $\mathrm{AAE}_{370-520 \mathrm{~nm}}$ and $\mathrm{AAE}_{520-880 \mathrm{~nm}}$ ranged from 0.81 to 2.31 and 0.91 to 2.13 , respectively. In the case of $\mathrm{BC}$, $\mathrm{AAE}_{\mathrm{BC}, 370-520 \mathrm{~nm} \text { and } \mathrm{AAE}} \mathrm{BC}_{520-880 \mathrm{~nm}}$ ranged from 0.59 to 0.98 and 0.82 to 1.15 , respectively. Using the absorption coefficients of $\mathrm{BC}$ calculated according to the Mie theory 

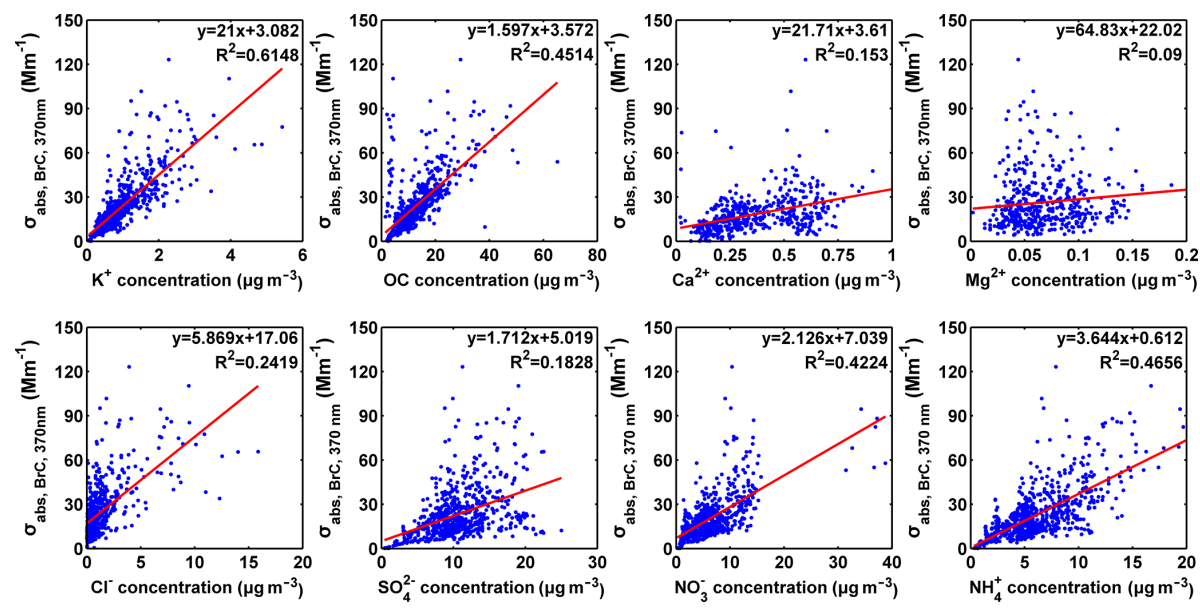

Figure 8. Correlations of the $\mathrm{BrC}$ absorption coefficient at $370 \mathrm{~nm}$ with $\mathrm{OC}$, water-soluble $\mathrm{K}^{+}, \mathrm{Ca}^{2+}, \mathrm{Mg}^{2+}, \mathrm{Cl}^{-}, \mathrm{SO}_{4}^{2-}, \mathrm{NO}_{3}^{-}$, and $\mathrm{NH}_{4}^{+}$ aerosol concentrations.
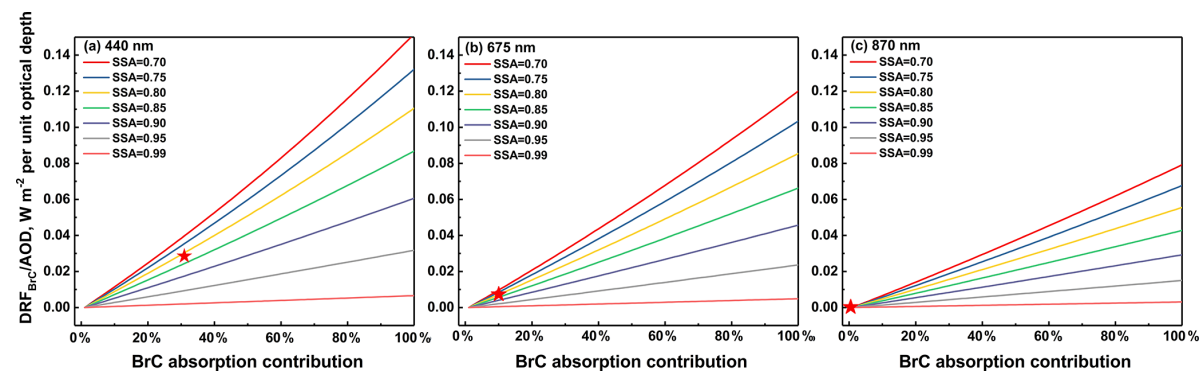

Figure 9. BrC radiative forcing efficiencies, which are defined as the $\mathrm{BrC}$ TOA direct radiative forcing divided by the AOD, as a function of the BrC-to-total-aerosol absorption ratio and SSA measured at the surface. The average AOD of the three wavelengths, the average ASY of the three wavelengths, a solar zenith angle of $55^{\circ}$, and average shortwave broadband surface albedo were used in the calculation. The red star corresponds to the average SSA and $\mathrm{BrC}$ absorption contributions determined from this campaign.

and the observed total aerosol absorption coefficients, we estimated the $\mathrm{AAE}_{\mathrm{BC}}$ and hence the $\mathrm{BrC}$ absorption contribution for the optically equivalent mixture configuration. The average $\mathrm{BrC}$ light absorption contribution ranged from $8.7 \% \pm 4.3 \%$ at $660 \mathrm{~nm}$ up to $34.1 \% \pm 8.0 \%$ at $370 \mathrm{~nm}$ when $\mathrm{AAE}_{\mathrm{BC}}$ was set as uniform. The sensitivity of $\mathrm{AAE}_{\mathrm{BC}}$ estimation associated with different RI and mixing state assumptions was further investigated. The results showed that variations in the real $\mathrm{RI}$ of the non-absorbing material (1.35

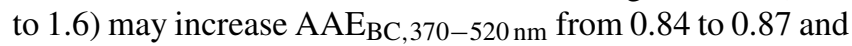

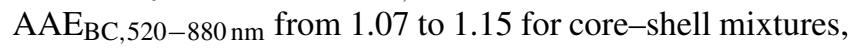

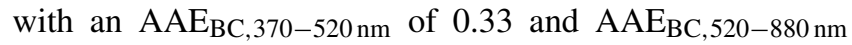
of 0.63 for external mixtures. Variations in the core's real RI (1.5 to 2.0) and imaginary RI (1.0 to 0.4$)$ may increase

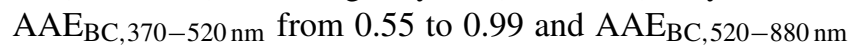
from 0.84 to 1.27 for the core-shell mixture and increase

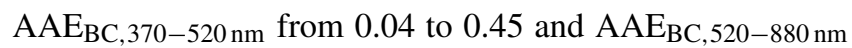
from 0.28 to 0.79 for the external mixture. These results indicate that the optical properties of the $\mathrm{BC}$ core and nonabsorbing material can significantly affect the accuracy of $\mathrm{AAE}_{\mathrm{BC}}$ and corresponding $\mathrm{BrC}$ absorption contribution es- timations. Compared to the values of $\mathrm{BrC}$ light absorption coefficient and $\mathrm{BrC}$ light absorption contribution from other similar studies conducted in the East Asia region, the $\mathrm{BrC}$ measured in this work showed relatively lower values of light absorption coefficient but was found to be responsible for relatively higher portion of light absorption. It should be noted that the calculated $\mathrm{BrC}$ light absorption may vary exponentially with the value of $\mathrm{AAE}_{\mathrm{BC}}$. According to Monte Carlo simulations under $95 \%$ confidence level, we found that $\mathrm{BrC}$ light absorption contribution ratios in this work can range roughly from $18 \%$ to $48 \%$ at $370 \mathrm{~nm}, 10 \%$ to $37 \%$ at $470 \mathrm{~nm}, 3 \%$ to $27 \%$ at $520 \mathrm{~nm}, 3 \%$ to $22 \%$ at $590 \mathrm{~nm}$, and $1 \%$ to $16 \%$ at $660 \mathrm{~nm}$. Therefore, proper values of $\mathrm{AAE}_{\mathrm{BC}}$ have to be carefully obtained for a particular study area, especially needing to be constrained by the BC mass concentration, size distribution, and mixing state measurements.

Additionally, the measurements of major water-soluble inorganic ions (including $\mathrm{K}^{+}, \mathrm{NO}_{3}^{-}$, and $\mathrm{NH}_{4}^{+}$) and particulate

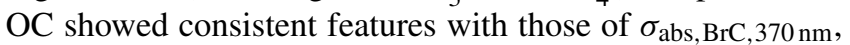
implying that $\mathrm{BrC}$ was associated with biomass burning emissions from nearby rural areas. Moreover, the diurnal 


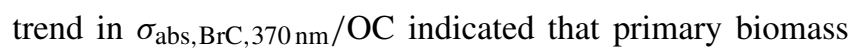
burning emissions can produce intense light-absorbing $\mathrm{BrC}$, while the photochemical aging process may weaken the light-absorbing capability of BrC.

Using a radiative transfer model (i.e., SBDART), we estimated the $\mathrm{BrC}$ effects on aerosol radiative forcing. The average shortwave aerosol direct radiative forcings due to scattering, $\mathrm{BrC}$ absorption, and $\mathrm{BC}$ absorption at the $\mathrm{TOA}$ were evaluated to be $-21.4 \pm 5.5 \mathrm{~W} \mathrm{~m}^{-2}, 2.3 \pm 1.8 \mathrm{~W} \mathrm{~m}^{-2}$, and $10.9 \pm 5.1 \mathrm{~W} \mathrm{~m}^{-2}$, respectively. BrC absorption accounted for $15.8 \% \pm 4.4 \%$ of the total shortwave solar absorption warming effect at the $\mathrm{TOA}$, indicating that $\mathrm{BrC}$ might be an important climate forcing agent, which is largely neglected in current climate models. To facilitate the estimation of the climate effects of $\mathrm{BrC}$, a set of lookup charts was constructed for the investigated area based on the default tropical atmosphere profile, average surface albedo, average asymmetry factor, and surface-measured aerosol properties (i.e., $\mathrm{BrC}$ absorption contribution, SSA, and AOD). Therefore, the role of the $\mathrm{BrC}$ radiative forcing efficiency at three wavelengths can be conveniently assessed for certain SSA and BrC absorption contributions.

Data availability. The field observation data and modeling parameters used in this study have been given as tables and time series plots in the Supplement. The sun photometer measurement data were acquired from the website of AERONET (https://aeronet.gsfc. nasa.gov/, last access: 3 August 2018; Nichol and Wong, 2005) and the surface albedo data were acquired from the website of MODIS (https://search.earthdata.nasa.gov/, last access: 23 August 2018; LP DAAC, 2000).

Supplement. The supplement related to this article is available online at: https://doi.org/10.5194/acp-19-11669-2019-supplement.

Author contributions. HT, JZ, YM, and CC designed the experiments, and ZL, LL, YQ, NW, FL, YL, and MC carried out the field measurements and data analysis. ZL and YQ performed Mie theory simulation. ZL, JZ, and HT prepared the paper with comments from all coauthors.

Competing interests. The authors declare that they have no conflict of interest.

Special issue statement. This article is part of the special issue "Multiphase chemistry of secondary aerosol formation under severe haze". It is not associated with a conference.

Acknowledgements. This work is supported by the National Key Project of MOST (2016YFC0201901, 2016YFC0203305, and
2016YFC0202401), the National Natural Science Foundation of China (41575122 and 41730106), and the National Research Program for Key Issues in Air Pollution Control (no. DQGG0103). We are also deeply thankful for Cheng Wu and the staff at the Hong Kong Polytechnic University site of AERONET.

Financial support. This research has been supported by the Ministry of Science and Technology of the People's Republic of China (grant nos. 2016YFC0201901, 2016YFC0203305, and 2016YFC0202401), the National Natural Science Foundation of China (grant nos. 41575122 and 41730106), and the National Research Program for Key Issues in Air Pollution Control (no. DQGG0103).

Review statement. This paper was edited by Jingkun Jiang and reviewed by three anonymous referees.

\section{References}

Andreae, M. O. and Gelencsér, A.: Black carbon or brown carbon? The nature of light-absorbing carbonaceous aerosols, Atmos. Chem. Phys., 6, 3131-3148, https://doi.org/10.5194/acp-63131-2006, 2006.

Andreae, M. O. and Merlet, P.: Emission of trace gases and aerosols from biomass burning, Global Biogeochem. Cy., 15, 955-966, 2001.

Ångström, A.: On the Atmospheric Transmission of Sun Radiation and on Dust in the Air, Geograf. Annal., 11, 156-166, 1929.

Arnott, W. P., Hamasha, K., Moosmüller, H., Sheridan, P. J., and Ogren, J. A.: Towards Aerosol Light-Absorption Measurements with a 7-Wavelength Aethalometer: Evaluation with a Photoacoustic Instrument and 3Wavelength Nephelometer, Aerosol Sci. Technol., 39, 17-29, https://doi.org/10.1080/027868290901972, 2005.

Arola, A., Schuster, G. L., Pitkänen, M. R. A., Dubovik, O., Kokkola, H., Lindfors, A. V., Mielonen, T., Raatikainen, T., Romakkaniemi, S., Tripathi, S. N., and Lihavainen, H.: Direct radiative effect by brown carbon over the Indo-Gangetic Plain, Atmos. Chem. Phys., 15, 12731-12740, https://doi.org/10.5194/acp-1512731-2015, 2015.

Bauer, J. J., Yu, X.-Y., Cary, R., Laulainen, N., and Berkowitz, C.: Characterization of the Sunset Semi-Continuous Carbon Aerosol Analyzer, J. Air Waste Manag. Assoc., 59, 826-833, https://doi.org/10.3155/1047-3289.59.7.826, 2012.

Bodhaine, B. A.: Aerosol absorption measurements at Barrow, Mauna Loa and the south pole, J. Geophys. Res.-Atmos., 100, 8967-8975, 1995.

Bohren, C. F. and Huffman, D. R.: Wiley: Absorption and Scattering of Light by Small Particles - Craig F. Bohren, Donald R. Huffman, Optics \& Laser Technology, 31, 328-328, 1983.

Bohren, C. F. and Huffman, D. R.: Absorption and Scattering of Light by Small Particles, WILEY-VCH Verlag GmbH \& Co, KGaA, 328-328 pp., 2007.

Bond, T. C., Bussemer, M., Wehner, B., Keller, S., Charlson, R. J., A., and Heintzenberg, J.: Light Absorption by Primary Particle 
Emissions from a Lignite Burning Plant, Environ. Sci. Technol., 33, 3887-3891, 1999.

Bond, T. C., Streets, D. G., Yarber, K. F., Nelson, S. M., Woo, J. H., and Klimont, Z.: A technology-based global inventory of black and organic carbon emissions from combustion, J. Geophys. Res.-Atmos., 109, 43, https://doi.org/10.1029/2003jd003697, 2004.

Bond, T. C., Zarzycki, C., Flanner, M. G., and Koch, D. M.: Quantifying immediate radiative forcing by black carbon and organic matter with the Specific Forcing Pulse, Atmos. Chem. Phys., 11, 1505-1525, https://doi.org/10.5194/acp-11-1505-2011, 2011.

Bricaud, A. and Morel, A.: Light attenuation and scattering by phytoplanktonic cells: a theoretical modeling, Appl. Opt., 25, 571, https://doi.org/10.1364/ao.25.000571, 1986.

Burling, I. R., Yokelson, R. J., Akagi, S. K., Urbanski, S. P., Wold, C. E., Griffith, D. W. T., Johnson, T. J., Reardon, J., and Weise, D. R.: Corrigendum to "Airborne and ground-based measurements of the trace gases and particles emitted by prescribed fires in the United States" published in Atmos. Chem. Phys., 11, 12197-12216, 2011, Atmos. Chem. Phys., 12, 103-103, https://doi.org/10.5194/acp-12-103-2012, 2012.

Chan, C. K. and Yao, X.: Air pollution in mega cities in China, Atmos. Environ., 42, 1-42, https://doi.org/10.1016/j.atmosenv.2007.09.003, 2008.

Cheng, Y., He, K.-B., Zheng, M., Duan, F.-K., Du, Z.-Y., Ma, Y.-L., Tan, J.-H., Yang, F.-M., Liu, J.-M., Zhang, X.-L., Weber, R. J., Bergin, M. H., and Russell, A. G.: Mass absorption efficiency of elemental carbon and water-soluble organic carbon in Beijing, China, Atmos. Chem. Phys., 11, 11497-11510, https://doi.org/10.5194/acp-11-11497-2011, 2011.

Cheng, Y. F., Eichler, H., Wiedensohler, A., Heintzenberg, J., Zhang, Y. H., Hu, M., Herrmann, H., Zeng, L. M., Liu, S., Gnauk, T., Brüggemann, E., and He, L. Y.: Mixing state of elemental carbon and non-light-absorbing aerosol components derived from in situ particle optical properties at Xinken in Pearl River Delta of China, J. Geophys. Res.-Atmos., 111, D20204, https://doi.org/10.1029/2005JD006929, 2006.

Cheung, H. H. Y., Tan, H., Xu, H., Li, F., Wu, C., Yu, J. Z., and Chan, C. K.: Measurements of non-volatile aerosols with a VTDMA and their correlations with carbonaceous aerosols in Guangzhou, China, Atmos. Chem. Phys., 16, 8431-8446, https://doi.org/10.5194/acp-16-8431-2016, 2016.

Collaud Coen, M., Weingartner, E., Apituley, A., Ceburnis, D., Fierz-Schmidhauser, R., Flentje, H., Henzing, J. S., Jennings, S. G., Moerman, M., Petzold, A., Schmid, O., and Baltensperger, U.: Minimizing light absorption measurement artifacts of the Aethalometer: evaluation of five correction algorithms, Atmos. Meas. Tech., 3, 457-474, https://doi.org/10.5194/amt-3-4572010, 2010.

Desyaterik, Y., Sun, Y., Shen, X., Lee, T., Wang, X., Wang, T., and Collett, J. L.: Speciation of "brown" carbon in cloud water impacted by agricultural biomass burning in eastern China, J. Geophys. Res.-Atmos., 118, 7389-7399, https://doi.org/10.1002/jgrd.50561, 2013.

Drinovec, L., Mocnik, G., Zotter, P., Prévôt, A. S. H., Ruckstuhl, C., Coz, E., Rupakheti, M., Sciare, J., Müller, T., Wiedensohler, A., and Hansen, A. D. A.: The "dual-spot" Aethalometer: an improved measurement of aerosol black carbon with real- time loading compensation, Atmos. Meas. Tech., 8, 1965-1979, https://doi.org/10.5194/amt-8-1965-2015, 2015.

Erlick, C., Abbatt, J. P. D., and Rudich, Y.: How Different Calculations of the Refractive Index Affect Estimates of the Radiative Forcing Efficiency of Ammonium Sulfate Aerosols, J. Atmos. Sci., 68, 1845-1852, https://doi.org/10.1175/2011jas3721.1, 2011.

Feng, X., Dang, Z., Huang, W., Shao, L., and Li, W.: Microscopic morphology and size distribution of particles in PM2.5 of Guangzhou City, J. Atmos. Chem., 64, 37-51, https://doi.org/10.1007/s10874-010-9169-7, 2010.

Feng, Y., Ramanathan, V., and Kotamarthi, V. R.: Brown carbon: a significant atmospheric absorber of solar radiation?, Atmos. Chem. Phys., 13, 8607-8621, https://doi.org/10.5194/acp13-8607-2013, 2013.

Hoffer, A., Gelencsér, A., Guyon, P., Kiss, G., Schmid, O., Frank, G. P., Artaxo, P., and Andreae, M. O.: Optical properties of humiclike substances (HULIS) in biomass-burning aerosols, Atmos. Chem. Phys., 6, 3563-3570, https://doi.org/10.5194/acp-6-35632006, 2006.

Holben, B. N., Eck, T. F., Slutsker, I., Tanré, D., Buis, J. P., Setzer, A., Vermote, E., Reagan, J. A., Kaufman, Y. J., and Nakajima, T.: AERONET - A Federated Instrument Network and Data Archive for Aerosol Characterization, Remote Sens. Environ., 66, 1-16, 1998.

Huang, R.-J., Zhang, Y., Bozzetti, C., Ho, K.-F., Cao, J.-J., Han, Y., Daellenbach, K. R., Slowik, J. G., Platt, S. M., Canonaco, F., Zotter, P., Wolf, R., Pieber, S. M., Bruns, E. A., Crippa, M., Ciarelli, G., Piazzalunga, A., Schwikowski, M., Abbaszade, G., SchnelleKreis, J., Zimmermann, R., An, Z., Szidat, S., Baltensperger, U., Haddad, I. E., and Prevot, A. S. H.: High secondary aerosol contribution to particulate pollution during haze events in China, Nature, 514, 218-222, https://doi.org/10.1038/nature13774, 2014.

Jiang, D., Wang, C., Wu, D., Deng, X., Huang, X., Tan, H., Li, F., and Deng, T.: Diurnal variation of atmospheric boundary layer over Wushan station, Guangzhou using wind profiler radar (in Chinese), J. Trop. Meteorol., 29, 129-135, 2013.

Jung, J., Lee, H., Kim, Y. J., Liu, X., Zhang, Y., Gu, J., and Fan, S.: Aerosol chemistry and the effect of aerosol water content on visibility impairment and radiative forcing in Guangzhou during the 2006 Pearl River Delta campaign, J. Environ. Manage., 90, 3231-3244, https://doi.org/10.1016/j.jenvman.2009.04.021, 2009.

Katrinak, K. A., Rez, P., Perkes, P. R., and Buseck, P. R.: Fractal geometry of carbonaceous aggregates from an urban aerosol, Environ. Sci. Technol., 27, 225-238, 1993.

Khalizov, A. F., Xue, H., Wang, L., Zheng, J., and Zhang, R.: Enhanced light absorption and scattering by carbon soot aerosol internally mixed with sulfuric acid, The J. Phys. Chem. A, 113, 1066-1074, https://doi.org/10.1021/jp807531n, 2009.

Kirchstetter, T. W., Novakov, T., and Hobbs, P. V.: Evidence that the spectral dependence of light absorption by aerosols is affected by organic carbon, J. Geophys. Res.-Atmos., 109, D21208, https://doi.org/10.1029/2004jd004999, 2004.

Kulkarni, P., Baron, P. A., and Willeke, K.: Aerosol measurement : principles, techniques, and applications, Van Nostrand Reinhold, 807-808 pp., 1996.

Lack, D. A. and Cappa, C. D.: Impact of brown and clear carbon on light absorption enhancement, single scatter albedo 
and absorption wavelength dependence of black carbon, Atmos. Chem. Phys., 10, 4207-4220, https://doi.org/10.5194/acp10-4207-2010, 2010.

Lack, D. A. and Langridge, J. M.: On the attribution of black and brown carbon light absorption using the Ångström exponent, Atmos. Chem. Phys., 13, 10535-10543, https://doi.org/10.5194/acp-13-10535-2013, 2013.

Lai, S.-C., Zou, S.-C., Cao, J.-J., Lee, S.-C., and Ho, K.-F.: Characterizing ionic species in PM2.5 and PM10 in four Pearl River Delta cities, South China, J. Environ. Sci., 19, 939-947, https://doi.org/10.1016/S1001-0742(07)60155-7, 2007.

Laskin, A., Laskin, J., and Nizkorodov, S. A.: Chemistry of atmospheric brown carbon, Chem. Rev., 115, 4335-4382, https://doi.org/10.1021/cr5006167, 2015.

Lee, E., Chan, C. K., and Paatero, P.: Application of positive matrix factorization in source apportionment of particulate pollutants in Hong Kong, Atmos. Environ., 33, 3201-3212, https://doi.org/10.1016/S1352-2310(99)00113-2, 1999.

Levine, J.: Biomass Burning Aerosols in a Savanna Region of the Ivory Coast, French Forum, 235-236, 1991.

Li, H., Han, Z., Cheng, T., Du, H., Kong, L., Chen, J., Zhang, R., and Wang, W.: Agricultural Fire Impacts on the Air Quality of Shanghai during Summer Harvesttime, Aerosol Air Qual. Res., 10, 95-101, https://doi.org/10.4209/aaqr.2009.08.0049, 2010.

Lin, P., Hu, M., Deng, Z., Slanina, J., Han, S., Kondo, Y., Takegawa, N., Miyazaki, Y., Zhao, Y., and Sugimoto, N.: Seasonal and diurnal variations of organic carbon in PM2.5 in Beijing and the estimation of secondary organic carbon, J. Geophys. Res., 114, D00G11, https://doi.org/10.1029/2008jd010902, 2009.

Liu, C., Chung, C. E., Yin, Y., and Schnaiter, M.: The absorption Ångström exponent of black carbon: from numerical aspects, Atmos. Chem. Phys., 18, 6259-6273, https://doi.org/10.5194/acp18-6259-2018, 2018.

Liu, D., Allan, J., Whitehead, J., Young, D., Flynn, M., Coe, H., McFiggans, G., Fleming, Z. L., and Bandy, B.: Ambient black carbon particle hygroscopic properties controlled by mixing state and composition, Atmos. Chem. Phys., 13, 2015-2029, https://doi.org/10.5194/acp-13-2015-2013, 2013.

Liu, D., Taylor, J. W., Young, D. E., Flynn, M. J., Coe, H., and Allan, J. D.: The effect of complex black carbon microphysics on the determination of the optical properties of brown carbon, Geophys. Res. Lett., 42, 613-619, 2015.

Liu, L., Mishchenko, M. I., and Patrick Arnott, W.: A study of radiative properties of fractal soot aggregates using the superposition T-matrix method, J. Quant. Spectrosc. Ra. Transf., 109, 26562663, https://doi.org/10.1016/j.jqsrt.2008.05.001, 2008.

LP DAAC: MODIS/surface albedo daily 500 m, February 2000 to Present, available at: https://developers.google.cn/earth-engine/ datasets/catalog/MODIS_006_MCD43A3 (last access: 3 August 2018), 2000.

Ma, N., Zhao, C. S., Müller, T., Cheng, Y. F., Liu, P. F., Deng, Z. Z., Xu, W. Y., Ran, L., Nekat, B., van Pinxteren, D., Gnauk, T., Müller, K., Herrmann, H., Yan, P., Zhou, X. J., and Wiedensohler, A.: A new method to determine the mixing state of light absorbing carbonaceous using the measured aerosol optical properties and number size distributions, Atmos. Chem. Phys., 12, 23812397, https://doi.org/10.5194/acp-12-2381-2012, 2012.

Ma, Y., Li, S. Z., Zheng, J., Khalizov, A., Wang, X., Wang, Z., and Zhou, Y. Y.: Size-resolved measurements of mix- ing state and cloud-nucleating ability of aerosols in Nanjing, China, J. Geophys. Res.-Atmos., 122, 9430-9450, https://doi.org/10.1002/2017jd026583, 2017.

Mie, G.: Beitrage Zur Optik Truber Medien, Speziell Kolloidaler Metallosungen, Ann. Phys., 25, 377, 1908.

Moosmüller, H., Chakrabarty, R. K., Ehlers, K. M., and Arnott, W. P.: Absorption Ångström coefficient, brown carbon, and aerosols: basic concepts, bulk matter, and spherical particles, Atmos. Chem. Phys., 11, 1217-1225, https://doi.org/10.5194/acp11-1217-2011, 2011.

Nakayama, T., Ikeda, Y., Sawada, Y., Setoguchi, Y., Ogawa, S., Kawana, K., Mochida, M., Ikemori, F., Matsumoto, K., and Matsumi, Y.: Properties of light-absorbing aerosols in the Nagoya urban area, Japan, in August 2011 and January 2012: Contributions of brown carbon and lensing effect, J. Geophys. Res.-Atmos., 119, 12721-712739, 2015.

Nichol, J. E. and Wong, M.-S.: AERONET/aerosol optical depth measurements at Hong Kong Polytechnic University, November 2005 to September 2019, available at: https://aeronet.gsfc.nasa. gov/photo_db/Hong_Kong_PolyU.html (last access: 23 August 2018), 2005.

Olson, M. R., Victoria Garcia, M., Robinson, M. A., Van Rooy, P., Dietenberger, M. A., Bergin, M., and Schauer, J. J.: Investigation of black and brown carbon multiple-wavelengthdependent light absorption from biomass and fossil fuel combustion source emissions, J. Geophys. Res.-Atmos., 120, 66826697, https://doi.org/10.1002/2014jd022970, 2015.

Pio, C. A., Legrand, M., Alves, C. A., Oliveira, T., Afonso, J., Caseiro, A., Puxbaum, H., Sanchez-Ochoa, A., and Gelencsér, A.: Chemical composition of atmospheric aerosols during the 2003 summer intense forest fire period, Atmos. Environ., 42, 7530 7543, 2008.

Qin, Y. M., Tan, H. B., Li, Y. J., Li, Z. J., Schurman, M. I., Liu, L., Wu, C., and Chan, C. K.: Chemical characteristics of brown carbon in atmospheric particles at a suburban site near Guangzhou, China, Atmos. Chem. Phys., 18, 16409-16418, https://doi.org/10.5194/acp-18-16409-2018, 2018.

Redmond, H. and Thompson, J. E.: Evaluation of a quantitative structure-property relationship (QSPR) for predicting mid-visible refractive index of secondary organic aerosol (SOA), Phys. Chem. Chem. Phys., 13, 6872-6882, https://doi.org/10.1039/c0cp02270e, 2011.

Ricchiazzi, P., Yang, S., Gautier, C., and Sowle, D.: SBDART: A Research and Teaching Software Tool for PlaneParallel Radiative Transfer in the Earth's Atmosphere, B. Am. Meteorol. Soc., 79, 2101-2114, https://doi.org/10.1175/15200477(1998)079<2101:Sarats>2.0.Co;2, 1998.

Roesch, A.: Use of Moderate-Resolution Imaging Spectroradiometer bidirectional reflectance distribution function products to enhance simulated surface albedos, J. Geophys. Res., 109, D12105, https://doi.org/10.1029/2004jd004552, 2004.

Sareen, N., Schwier, A. N., Shapiro, E. L., Mitroo, D., and McNeill, V. F.: Secondary organic material formed by methylglyoxal in aqueous aerosol mimics, Atmos. Chem. Phys., 10, 997-1016, https://doi.org/10.5194/acp-10-997-2010, 2010.

Satish, R., Shamjad, P., Thamban, N., Tripathi, S., and Rastogi, N.: Temporal Characteristics of Brown Carbon over the Central Indo-Gangetic Plain, Environ. Sci. Technol., 51, 6765-6772, https://doi.org/10.1021/acs.est.7b00734, 2017. 
Scarnato, B. V., Vahidinia, S., Richard, D. T., and Kirchstetter, T. W.: Effects of internal mixing and aggregate morphology on optical properties of black carbon using a discrete dipole approximation model, Atmos. Chem. Phys., 13, 5089-5101, https://doi.org/10.5194/acp-13-5089-2013, 2013.

Schmid, O., Artaxo, P., Arnott, W. P., Chand, D., Gatti, L. V., Frank, G. P., Hoffer, A., Schnaiter, M., and Andreae, M. O.: Spectral light absorption by ambient aerosols influenced by biomass burning in the Amazon Basin. I: Comparison and field calibration of absorption measurement techniques, Atmos. Chem. Phys., 6, 3443-3462, https://doi.org/10.5194/acp-6-3443-2006, 2006.

Segura, S., Estellés, V., Titos, G., Lyamani, H., Utrillas, M. P., Zotter, P., Prévôt, A. S. H., Močnik, G., Alados-Arboledas, L., and Martínez-Lozano, J. A.: Determination and analysis of in situ spectral aerosol optical properties by a multiinstrumental approach, Atmos. Meas. Tech., 7, 2373-2387, https://doi.org/10.5194/amt-7-2373-2014, 2014.

Seinfeld, J. H. and Pandis, S. N.: Atmospheric Chemistry and Physics, John Wiley \& Sons, Inc, New York, 1998.

Stokes, G. M. and Schwartz, S. E.: The Atmospheric Radiation Measurement (ARM) Program: Programmatic Background and Design of the Cloud and Radiation Test Bed, B. Am. Meteorol. Soc., 75, 1201-1221, 1994.

Tan, H., Liu, L., Fan, S., Li, F., Yin, Y., Cai, M., and Chan, P. W.: Aerosol optical properties and mixing state of black carbon in the Pearl River Delta, China, Atmos. Environ., 131, 196-208, https://doi.org/10.1016/j.atmosenv.2016.02.003, 2016a.

Tan, H., Yin, Y., Li, F., Liu, X., Chan, P. W., Deng, T., Deng, X., Wan, Q., and Wu, D.: Measurements of particle number size distributions and new particle formations events during winter in the Pearl River Delta region, China, J. Trop. Meteorol., 22, 191-199, 10.16555/j.1006-8775.2016.02.009, 2016b.

Waldman, J. M., Lioy, P. J., Zelenka, M., Jing, L., Lin, Y. N., He, Q. C., Qian, Z. M., Chapman, R., and Wilson, W. E.: Wintertime measurements of aerosol acidity and trace elements in Wuhan, a city in central China, Atmos. Environ. Part B., 25, 113-120, https://doi.org/10.1016/0957-1272(91)90045-G, 1991.

Wang, J., Nie, W., Cheng, Y., Shen, Y., Chi, X., Wang, J., Huang, X., Xie, Y., Sun, P., Xu, Z., Qi, X., Su, H., and Ding, A.: Light absorption of brown carbon in eastern China based on 3-year multiwavelength aerosol optical property observations and an improved absorption Ångström exponent segregation method, Atmos. Chem. Phys., 18, 9061-9074, https://doi.org/10.5194/acp18-9061-2018, 2018.
Washenfelder, R. A., Attwood, A. R., Brock, C. A., Guo, H., Xu, L., Weber, R. J., Ng, N. L., Allen, H. M., Ayres, B. R., and Baumann, K.: Biomass burning dominates brown carbon absorption in the rural southeastern United States, Geophys. Res. Lett., 42, 653664, 2015.

Wex, H., Neusüß, C., Wendisch, M., Stratmann, F., Koziar, C., Keil, A., Wiedensohler, A., and Ebert, M.: Particle scattering, backscattering, and absorption coefficients: An in situ closure and sensitivity study, J. Geophys. Res.-Atmos., 107, LAC-1LAC4-18, https://doi.org/10.1029/2000JD000234, 2002.

Wu, C., Wu, D., and Yu, J. Z.: Quantifying black carbon light absorption enhancement with a novel statistical approach, Atmos. Chem. Phys., 18, 289-309, https://doi.org/10.5194/acp-18-2892018, 2018.

Wu, C., Wu, D., and Yu, J.: Estimation and Uncertainty Analysis of Secondary Organic Carbon Using One-Year of Hourly Organic and Elemental Carbon Data, J. Geophys. Res.-Atmos., 124, 2774-2795, https://doi.org/10.1029/2018JD029290, 2019.

Wu, D., Mao, J., Deng, X., Tie, X., Zhang, Y., Zeng, L., Li, F., Tan, H., Bi, X., Huang, X., Chen, J., and Deng, T.: Black carbon aerosols and their radiative properties in the Pearl River Delta region, Sci. China D, 52, 1152-1163, https://doi.org/10.1007/s11430-009-0115-y, 2009.

Xie, C., Xu, W., Wang, J., Wang, Q., Liu, D., Tang, G., Chen, P., Du, W., Zhao, J., Zhang, Y., Zhou, W., Han, T., Bian, Q., Li, J., Fu, P., Wang, Z., Ge, X., Allan, J., Coe, H., and Sun, Y.: Vertical characterization of aerosol optical properties and brown carbon in winter in urban Beijing, China, Atmos. Chem. Phys., 19, 165179, https://doi.org/10.5194/acp-19-165-2019, 2019.

Yu, J., Yan, C., Liu, Y., Li, X., Zhou, T., and Zheng, M.: Potassium: A Tracer for Biomass Burning in Beijing?, Aerosol Air Qual. Res., 18, 2447-2459, https://doi.org/10.4209/aaqr.2017.11.0536, 2018.

Yuan, J.-F., Huang, X.-F., Cao, L.-M., Cui, J., Zhu, Q., Huang, C.N., Lan, Z.-J., and He, L.-Y.: Light absorption of brown carbon aerosol in the PRD region of China, Atmos. Chem. Phys., 16, 1433-1443, https://doi.org/10.5194/acp-16-1433-2016, 2016.

Zhang, Y., Li, Z., Sun, Y., Lv, Y., and Xie, Y.: Estimation of atmospheric columnar organic matter (OM) mass concentration from remote sensing measurements of aerosol spectral refractive indices, Atmo. Environ., 179, 107-117, https://doi.org/10.1016/j.atmosenv.2018.02.010, 2018.

Zhou, S., Wang, T., Wang, Z., Li, W., Xu, Z., Wang, X., Yuan, C., Poon, C. N., Louie, P. K. K., Luk, C. W. Y., and Wang, W.: Photochemical evolution of organic aerosols observed in urban plumes from Hong Kong and the Pearl River Delta of China, Atmos. Environ., 88, 219-229, https://doi.org/10.1016/j.atmosenv.2014.01.032, 2014. 